\title{
Stock Market Reactions to Financing and Payment Decisions for European Mergers and Acquisitions
}

\section{Wolfgang BESSLER}

\section{University of Hamburg, Germany / University of Groningen, The Netherlands David KRUIZENGA}

University of Groningen, The Netherlands

Wim WESTERMAN

University of Groningen, The Netherlands

\begin{abstract}
:
Aim: We analyze stock market reactions to merger and acquisition announcements for firms in Europe and contribute to the literature by providing empirical evidence how the decisions with respect to alternative financing sources (equity or debt) and methods of payment (cash or stock) affect the magnitude of the valuation effects.
\end{abstract}

Research design: An event study methodology is applied to 717 M\&A transactions. We analyze the size of the cumulative abnormal returns using the financing sources and payment methods and other variables as the relevant determinants.

Findings: The cumulative abnormal results suggest that target shareholders and bidder shareholders in private deals benefit from mergers and acquisitions. The effect found is centered around the announcement date, making our findings consistent with market efficiency. Debt financed deals outperform equity financed deals and cash paid M\&A outperform stock paid M\&As due to information asymmetries as well as signaling and agency effects.

Originality: This study adds to our understanding of the relevance of the financing sources and the payment methods for the magnitude of valuation effects of mergers and acquisitions in Europe.

Implications: This study may help practitioners to better assess the valuation effects of alternative financing sources and payment methods when acquiring other firms.

Key words: mergers \& acquisitions, abnormal returns, financing sources, payment methods, Europe JEL: G32, G34

Correspondence address: Wim WESTERMAN, University of Groningen, The Netherlands, E-mail: w.westerman@rug.nl (Wim WESTERMAN); w.h.bessler@rug.nl (Wolfgang BESSLER); kruizenga.db@gmail.com (David KRUIZINGA).

Received: 10.01.2020, Revised: 28.02.2020, Accepted: 28.02.2020

doi: http://dx.doi.org/10.29015/cerem.866. 


\section{Introduction}

Mergers and acquisitions (M\&A) are major corporate strategy and investment decisions, often containing tremendous uncertainty and risks for the firms involved as the outcome is often difficult to predict. During the last two decades, the M\&A activity in the U.S. has grown rapidly and has become a popular means for many firms to expand their business activities as well as for gaining access to new growth opportunities (Bessler et al. 2017). Historically, most M\&A studies focused on the financial markets in the United States and the United Kingdom, since mergers and acquisitions are an important corporate control mechanism in these markets. Therefore, M\&As are of greater importance and consequently the deal numbers and values are higher. The M\&A activity in Continental Europe has been relatively smaller due to the different corporate governance systems and the banks' dominance in firm financing and its influence through various corporate governance mechanisms. Nevertheless, the M\&A activity in Europe has increased substantially subsequent to the financial crisis in 2008/2009 and is nowadays much more pronounced, attracting more academic research. However, many aspects are still unexplored for European M\&As such as the mechanisms and determinants for the choice between different financing alternatives and the decision on the method of payment.

When a merger or acquisition is publicly announced, considerable information of the potential transaction and its possible consequences become public knowledge. The stock market reactions to the announcement represents the capital markets' expectation of the possible takeover benefits (Asquith 1983). Therefore, the announcement of a merger should result instantaneously in a new valuation of the bidder and the target, and if the markets are efficient (Fama 1965, 1990), this stock price adjustment should be immediate, fully reflecting all information. Consequently, there should be no significant stock price reaction during the periods before or subsequent to the M\&A announcement. To investigate this hypothesis, it is appropriate that most corporate finance studies on merger announcements use the event study methodology (e.g., MacKinlay 1997) in which the capital market's 
valuation effects of the bidder and the target firms during the event period are analyzed. In our study, we also perform an event study by investigating the effects of different financing decisions as well as the choice of the method of payment on the magnitude of the stock price reactions around an M\&A announcement.

The focus of our research is on the effects that alternative financing sources and methods of payment have on the valuation of the firms. Bessler, Drobetz and Zimmerman (2011) argue that it is theoretically possible that both determinants are viewed independently from each other and that their effect on the firm's value can be analyzed individually as well as jointly. There are a few studies supporting the ideas and discussion of Bessler, Drobetz and Zimmermann (2011), such as Bharadwaj and Shivdasani (2003), Martynova and Renneboog (2009) and Fischer (2017). Fischer (2017) discusses the limitations in understanding the alternative financing sources and suggests that further research should focus only on the dominant source of financing. Our research addresses this issue and assumes that the bidders' financing source is either debt or equity and the method of payment is either cash or shares. Consequently, the transactions using mixed financing sources or methods of payment are excluded. Most importantly, we combine the financing sources with the methods of payment and investigate their interaction effects from different perspectives.

The remainder of this article proceeds as follows. In the next section, we discuss the different financial theories applicable to our research as well as the empirical findings related to financing decisions and methods of payment in M\&As. We also derive and present our hypotheses in this section. Section three describes the data on European companies, and the methodology employed in our research is outlined in section four. The empirical results of our study are presented and discussed in section five. Section six concludes.

\section{Literature review}

This study combines two major research streams within the corporate finance literature: capital structure theories and mergers and acquisitions as well as their 


\section{Wolfgang BESSLER, David KRUIZENGA, Wim WESTERMAN}

respective empirical evidence. The source of financing and the method of payment are related to both streams and we interpret and treat them as the essential link between both research areas. Therefore, this section begins with a brief discussion of capital structure theories and especially the pecking-order theory (Myers, Majluf 1984), which might explain the ranking of financing sources of M\&As. It continues with a discussion of the empirical evidence related to mergers and acquisitions. This section is further divided into two parts discussing first the empirical evidence of the financing sources and second the methods of payment in M\&As.

\subsection{Capital structure theories related to $M \& A s$}

Many different theories have been advanced explaining the optimal capital structure of firms. All of them have been empirically tested in many studies for different countries and capital markets (see e.g., Bessler et al. 2008; Bessler, Drobetz, Kazemieh 2011). However, no consensus has been reached so far as this represents a multi-dimensional problem. One of the prominent theories with substantial empirical support are the pecking order theory (Myers, Majluf 1984) and the dynamic pecking-order-theory (Bessler et al. 2014). The pecking-order theory suggests that the cost of financing increases with higher information asymmetry between the firms and its debt and equity holders. Asymmetric information usually implies that one party (management) has better information than the other party (equity and debt holders). Therefore, firms would typically use the financing instrument that has the least information asymmetry and therefore the least relative costs at that moment, resulting in the pecking order of first using internal funds, second debt, and finally equity, making equity the least attractable and most expensive financing alternative. This idea is widely studied in the principal-agent literature and it is fundamental to the signaling theory of Spence (1973). Myers and Majluf (1984) assume in their pecking order theory that management is better informed about the firm's value than outside investors are. An extension of the basic static model results in the dynamic pecking order theory (Bessler et al. 2014). The outcome of this theory and the empirical evidence suggests that firms would issue equity, and often more equity than currently needed, when the information asymmetry between management and investors is at present relatively low. In these 
situations, management could build-up cash reserves for future acquisitions. This might be one explanation why firms issue first equity (seasoned equity offering) and then later on employ these cash proceeds as the payment method in an M\&A. In any case, access to any form of financing is essential for an M\&A (Cornaggia, Li 2019).

If management decides to issue new equity nevertheless, indicating that this is the cheapest financing alternative currently available, this decision contains different signals and potential investors usually interpret this in a way that managers know that their shares are overvalued and hence may take advantage of this over-valuation (Golubov et al. 2016; Samer, Barbopoulos 2018). Therefore, investors may place immediately a lower value on the firm, resulting in negative valuation effects and a decline of the share price and the market value of the firm. In contrast, debt issuance signals the companies' confidence that the investment is profitable and the stock price is possibly undervalued. Thus, debt issues are typically preferred over equity issues, which is consistent with the pecking order theory, and for this reason the theory may be employed to explain the financing decisions. Again, the conclusion for the basic form of the pecking-order-theory is that companies prioritize their financing decisions based on the cost of financing. Therefore, companies use internal funds first, followed by debt and equity last.

\subsection{Mergers and acquisitions}

\subsubsection{M\&A motives}

The fundamental objective of mergers and acquisitions is the realization of synergies to develop corporate growth, increase market power, boost profitability, and improve shareholders' wealth (Alexandris et al. 2010; Alexandridis et al. 2017). However, economic theory provides many more reasons for companies engaging in merger activities (Andrade et al. 2001). Possible reasons are centered around efficiency-related purposes involving economies of scale, attempts to create market power, and taking advantage of diversification opportunities. Mitchell and Mulherin (1996) suggest that mergers occur in waves, which are often a reaction to unexpected shocks in industries or technologies. Studies such as Andrade et al. (2001) and Mitchell and Mulherin (1996) provide evidence that merger activity also clusters by industry. In the earlier literature, the main idea among a few others was 


\section{Wolfgang BESSLER, David KRUIZENGA, Wim WESTERMAN}

that synergies could be realized by economies of scale, vertical integration, and the adoption of more efficient technologies (Jensen, Ruback 1983). This earlier research provided evidence that M\&A gains do not result from gaining market power, contrary to later research conducted by Andrade et al. (2001) and Alexandris et al. (2010). Consequently, the explanations for M\&A waves and M\&A activity is time varying and may have adjusted over time (Alexandridis 2012; Xu 2017).

One of the pivotal questions is how possible M\&A related synergy gains are distributed between bidder and target shareholders. There exists a large body of empirical literature in corporate finance how the takeover gains are split between target and bidding firms' shareholders (Alexandridis et al. 2013). Most studies such as Jensen and Ruback (1983) and Andrade et al. (2001) provide evidence that the shareholders of target firms benefit the most from mergers. Some studies suggest that the entire synergy gains are reflected in the takeover premium and therefore are absorbed by the target shareholders (Bessler, Schneck 2015) as they are only willing to tender their shares when they receive this premium. Increases of offer prices during the negotiation period are evidence of this behavior. Therefore, it is an important decision to determine the optimal offer price strategy to prevent bidder competition, being successful in the end by paying the lowest or minimum price for the target (Bessler et al. 2015). The method of payment is one important ingredient in this strategy as is the source of financing. Both aspects provide an important motivation for this research.

The dissimilarities in takeover gains may be due to information asymmetry and uncertainty about the outcome and profitability of a merger and acquisition. Information asymmetry and uncertainty in mergers affect deal characteristics and wealth creation for both parties (Moeller et al. 2005; Luypaert, Van Caneghem 2017). Luypaert and Van Cangehem (2017) argue that the wealth realized by the bidder depends on the accurate assessment of the target value and synergistic effects. In contrast, wealth effects for target firms depend on bidder value and potential synergistic gains. Additionally, Alexandris, Fuller, Terhaar and Travlos (2013) report that the returns of bidders depend on concerns about the strategic potential and complexity of the deal. 
All empirical evidence and discussion suggest that M\&As are risky investments as the outcome is typically highly uncertain (Fich et al. 2018; Malmendier et al. 2018). Therefore, many merges and acquisitions do not create value ex-post but often destroy value for the shareholders of the bidder and the target firms if they stay invested. Given this inherent riskiness in M\&As, management has different alternatives of how to cope with this uncertainty or how to minimize the negative long-term valuation effects on the bidder firm. One aspect is to decide how to finance the deal, the other is how to pay for the deal. Financing alternatives are either issuing new equity or debt, or using internal funds, which may come from previously issued equity or debt or from operational cash flows. The second aspect is the method of payment, or how to pay for the deal. The means are either cash or shares of the bidder or a combination of both. In the next two sections, we discuss the financing alternatives and the method of payment decision in more detail.

\subsubsection{Financing decisions}

Many empirical studies have focused on the alternative financing sources and methods of payment in corporate takeovers. In most research (Faccio, Masulis 2005; Harford et al. 2009; Vermaelen, Xu 2014), the 'method of payment' is used as synonymous with the 'sources of takeover financing'. Bessler, Drobetz and Zimmermann (2011) argue that the method of payment and the sources of financing are independent of each other and thus should be treated and analyzed separately as well as jointly. The argument is similar to the capital structure and dividend policy irrelevance argument of Modigliani and Miller (1958, 1961), suggesting that the financing (debt or equity) and the method of payment (cash or shares) decisions are in theory independent of each other and substitutable in perfect capital markets without asymmetric information and financial signaling. As already argued before, issuing new equity to finance the deal can result in both cash and shares as a method of payment. Issuing new debt usually results in cash payments and less likely in share deals. So far, this perspective has only been briefly discussed for M\&As. A few studies are consistent with the interpretation of Bessler, Drobetz and Zimmermann (2011), such as Bharadwaj and Shivdasani (2003), Martynova and Renneboog (2009) and Fischer (2017). This study follows the perspectives of 


\section{Wolfgang BESSLER, David KRUIZENGA, Wim WESTERMAN}

Bessler, Drobetz and Zimmermann (2011), but the other three studies that suggest that the financing sources are independent from the payment methods are discussed as well.

First, Bharadwaj and Shivdasani (2003) examine a sample of 115 cash tender offers between 1990 and 1996. Their study differs from prior research as the authors focus on the source of financing separately from the method of payment. They investigate under which circumstances acquisitions are bank financed before making a bid. Bank financing is superior when an acquirer has a low cash reserve, or the relative size of the takeover is large. The authors suggest that the abnormal returns around the announcement date are higher for acquisitions financed with bank debt as compared to acquisitions financed with internal funds. However, this advantage could also be due to the signaling effects coming from the monitoring bank that extended or granted the new loans (Slovin et al. 1993). As this study includes only cash tender offers, it is unable to differentiate clearly between financing decisions and payment methods.

Secondly, Martynova and Renneboog (2009) link the method of payment to the source of financing for a European M\&A sample. They classified takeovers by the sources of financing to test the predictions from pecking order and market timing theories (Myers, Majluf 1984), regulatory environment (La Porta et al. 1997), debt overhang (Myers 1977) and the agency cost of debt and equity (Jensen, Meckling 1976), among others. This enables them to measure the additional performance of companies that choose the source of financing and the payment method independently. They claim: “.... investors take into account the information signaled by the choices of both the payment method and the sources of takeover financing when estimating the possible synergies of the takeover announcement" (Martynova, Renneboog 2009: 28). The authors find that debt financing outperforms internal financing. Consequently, debt financing sends a positive signal to the market that the shares of the bidder is not overvalued.

Fischer (2017) expands the analysis by claiming that the 'connected model' of Martynova and Renneboog (2009) explains the source of financing to be dominated by the method of payment. Therefore, the author suggests that internal funds are used for smaller takeovers and additionally external funds are required for larger 
deals. Hence, he argues that the source of financing is decided in a two-stage process, in which consistent with the pecking-order theory, internal funds are preferred over external funds (Myers, Majluf 1984). Fischer (2017) expects that M\&As using internal funds perform better than M\&As financed with debt or equity.

In line with the pecking order and other theories, we expect that debt financing results in higher abnormal returns than equity financing around the merger announcement, which leads to our first hypothesis:

\section{Hypothesis 1: Debt financing outperforms equity financing in the short run.}

\subsubsection{Payment methods}

The choice of the method of payment is essential for any deal, since cash and share offers differ with respect to the allocation of the transaction risks. The differences may be due to information asymmetry and disparities in the pricing mechanisms (Bessler, Drobetz, Zimmermann 2011). The bidder could be overpaying the target or face concerns that the offer is too low. Therefore, targets may reject the offer or attract competing bidders, making the acquisition more expensive (Bessler et al. 2015; Peng et al. 2016; Sankar, Bijay 2018). Therefore, the bidder has to decide on the method of payment prior to making an offer. When bidder shares seem to be overvalued or when risk-sharing motives are essential for the acquirer's shareholders, stock payments are preferred over cash payments (Martynova, Renneboog 2009; Bessler, Drobetz, Zimmermann 2011; Cho, Ahn 2017). If other factors play a more important role in the payment decision, cash offers may be preferred (Luypaert, Van Caneghem 2017). Prior research indicates that due to information asymmetry and valuation uncertainty of M\&A deals, the markets usually treat a stock payment less favorable than a cash payment (see e.g. Fuller et al. 2002; Moeller et al. 2005; Luypaert, Van Caneghem 2017). Furthermore, cash hoarding of acquirers can strengthen the negative signal if they finance their deal with stock (Lie, Liu 2018). Nevertheless, Ismail and Krause (2010) argue that there is still a significant gap in understanding the determinants of the payment methods, although a large body of literature exists. 
Goergen and Renneboog (2004) find in a study of European domestic and crossborder takeovers strong evidence that cash payments trigger substantially higher abnormal returns than equity offers and/or combined offers. Dutta, Saadi and Zhu (2013) analyze Canadian cross-border deals suggesting that their insignificant findings on payment methods can be due to the relative size of the cross-border deals. Huang, Officer and Powell (2016) indicate that the method of payment has more implications for cross-border than for domestic mergers as the country-level risk factors significantly influence the choice of the payment method. Finally, Mateev (2017) provides evidence that for the United Kingdom and Continental European stock paying bidders achieve better results than cash paying bidders. Empirical evidence by Fuller et al. (2002) and Moeller, Schlingemann and Stulz (2005) support the idea that shareholders of the acquiring firm view cash offers more positively than equity offers. Consequently, the results reveal higher abnormal returns for acquisitions when financed with internal funds. Moreover, based on the pecking order theory, Martynova and Renneboog (2009), Fischer (2017) and Mateev (2017) find that cash offers generate higher abnormal returns than equity offers around the merger announcement. Based on the theory and the empirical evidence we expect that bidders that pay with cash outperform bidders that pay with shares and derive our second hypothesis:

\section{Hypothesis 2a: Cash payments outperform stock payments in the short run.}

Studies such as Lie and Liu (2018) and Ismail and Krause (2010) indicate that targets earn positive abnormal returns for both stock and cash payments after the announcement. The authors argue that cash payments are favorable for target shareholders, in line with the theory of Majluf and Myers (1984). Vermaelen and Xu (2015) shed an interesting view on the payment method as they suggest that cash payments may indicate that the acquirer's stock is undervalued. This would be irrelevant to the target firm because a cash transaction is not sensitive to the acquirer's stock price. Yet, since the target firm knows less about the true value of the acquirer, substantial information asymmetry might become evident. Asymmetric 
information is usually measured by the Tobin's Q, which measures the ratio of market value to book value.

Our objective is to examine the effect of the acquirer's market-to-book-ratio on the target returns in cash paid takeovers. The literature assumes that bidders pay with cash when their stock is undervalued and capital markets expect these companies to have low market to book ratios $($ e.g. $M / B<1)$. Therefore, we expect that acquirers with a high market-to-book-ratio create more wealth for the target shareholders in cash paid takeovers as they are overvalued (see e.g., Ismael, Krause 2010; Vermaelen, Xu 2015). This results in our next hypothesis:

\section{Hypothesis 2b: A high M/B ratio of the bidder creates a higher wealth effect for target shareholders compared to a low $\mathrm{M} / \mathrm{B}$ ratio of the bidder in a cash paid takeover.}

In section 2, we reviewed and discussed the literature and developed our hypotheses, relying on the previous empirical findings of capital structure and M\&A research. Both single and multiple regression models will be implemented in section five to investigate how the decision on the financing and payment methods affect shareholder value. In the next two sections we present our data and the methodology.

\section{Data}

This section consists first of a description of our data and data sources (3.1). We then introduce the dependent and independent variables (3.2.) as well as the control variables (3.3) and provide information on the sample distributions.

\subsection{Data description}

The transaction data of the deals are obtained from the Zephyr database from Bureau van Dijk. The sample includes M\&A deals completed between January 1997 
and December 2016. Only European transactions are included, which means that the headquarters of the bidders and targets are located in Continental Europe (CE) and/or the United Kingdom/Ireland (UK). The bidders must be publicly listed as we investigate valuation effects (stock price reactions). However, the targets include both public and private firms. The initial stake of the bidder in the target has to be below 50\% before the deal and above 50\% after deal completion. Furthermore, the transaction value is at least 1 million Euro and multiple deals from the same bidder are included as long as they do not overlap within the estimation periods. Given the focus of our research, the following additional information are required which we gather from Zephyr: the method of payment, the financing source, and the deal value in Euro.

The initial sample includes 1,780 European transactions. Stock prices were obtained from Datastream / Thomson Reuters for the period around the events. Some transactions had to be omitted from the final sample due to the small firm size and data restrictions. The final sample consists of 717 transactions, which is equal to the sample of total bidders. Most of the acquisitions involve private targets for which daily market values are not available and the event study methodology is therefore not applicable here. The sample of target firms consists of 102 public companies, and for 92 companies the valuation effects are investigated. Table 1 below displays how the data restrictions reduce our sample size.

\section{Table 1. Sample restrictions}

\begin{tabular}{|l|r|}
\hline Criteria & Remaining deals \\
\hline Information on payment method & 203,102 \\
\hline Information regarding financing sources & 12,751 \\
\hline Information on initial and acquired stake & 7,070 \\
\hline Transaction within the time period & 5,742 \\
\hline Deals in Europe & 1,780 \\
\hline Covered by Datastream & 980 \\
\hline Deals by Datastream & 717 \\
\hline
\end{tabular}




\subsection{Dependent and independent variables}

This study investigates how financing decisions and the methods of payment of M\&A deals in Europe affect the financial performance of bidders and targets. As an event study is conducted to measure the valuation effects, the dependent variable is abnormal returns. The independent variables are the financing sources, the methods of payment, the market-to-book-ratio of the bidder, and whether the transaction is a domestic or cross-border deal. Dummy variables are used for the independent variables, and are specified as follows:

- $\quad$ Financing source $=[$ Debt $=1$, Equity $=0]$.

- Payment method $=[$ Cash $=1$, Shares $=0]$.

- Internationalization $=[$ Cross-border $=1$, Domestic $=0]$.

- Market-to-Book $=[\mathrm{M} / \mathrm{B}<1=0, \mathrm{M} / \mathrm{B}>0=1]$.

\subsection{Control variables}

We include a set of control variables in our regression analyses to investigate whether any of these controls affect the results. The set of control variables includes: (i) deal specific characteristics; (ii) firm specific characteristics; and (iii) country specific characteristics. The variety of variables are similar to those used in other studies (see e.g. Martynova, Renneboog 2009; Dutta et al. 2013; Huang et al. 2016; Mateev 2017). The accounting variables and stock returns are winsorized at the lower $1 \%$ and upper $99 \%$ level to remove outliers. Deal specific variables other than the dependent variables include the deal value and the deals per industry. For this we use the ten category classification benchmark of FTSE Russell. The FTSE Russell is a benchmark adopted globally for categorizing companies across industries, sectors, and subsectors. Furthermore, we include dummy variables for firms from the utility and financial industries, which are usually excluded from most studies due their specific business and higher regulation (Kahle, Walkling 1996) and different financial characteristics such as high leverage levels (Fama, French 1992; Kahle, Walkling 1996). 
Wolfgang BESSLER, David KRUIZENGA, Wim WESTERMAN

Table 2. Variable definitions

\begin{tabular}{|c|c|c|}
\hline Variable & Description & Source \\
\hline AR Acquirer (\%) & \multirow{2}{*}{$\begin{array}{l}\text { Acquirer's abnormal returns. The abnormal return is the } \\
\text { difference between the firm's returns and the returns of } \\
\text { the market model (STOXX). Stock prices are adjusted } \\
\text { for stock splits and dividends. * }\end{array}$} & Datastream \\
\hline & & \\
\hline \multirow[t]{2}{*}{ AR Target $(\%)$} & \multirow{2}{*}{$\begin{array}{l}\text { Target's abnormal returns. The abnormal return is the } \\
\text { difference between the firm's returns and the returns of } \\
\text { the market model (STOXX). Stock prices are adjusted } \\
\text { for stock splits and dividends. * }\end{array}$} & Datastream \\
\hline & & \\
\hline Financing source & \multirow{2}{*}{$\begin{array}{l}\text { Financing source of the acquirer expressed as a dummy. } \\
\text { Takes a value of "1" for Debt, and "0" for Equity. }\end{array}$} & Zephyr \\
\hline & & \\
\hline Payment method & \multirow{2}{*}{$\begin{array}{l}\text { Payment method of the acquirer expressed as a dummy. } \\
\text { Takes a value of " } 1 \text { " for Cash, and " } 0 \text { " for Shares. }\end{array}$} & Zephyr \\
\hline & & \\
\hline Transaction value & The deal value in the takeover shown in Euro. & Zephyr \\
\hline Tobin’s Q & $\begin{array}{l}\text { Market to book ratio of the acquirer, which is the market } \\
\text { value divided by the book value. }\end{array}$ & Datastream \\
\hline $\mathrm{M} / \mathrm{B}$ dummy & $\begin{array}{l}\text { Dummy whether the acquirer's stock is overvalued or } \\
\text { undervalued. The variable is expressed as a dummy. } \\
\text { Takes a value of " } 1 \text { " for overvalued stocks, and " } 0 \text { " for } \\
\text { undervalued stocks. }\end{array}$ & $\begin{array}{l}\text { Authors' } \\
\text { calculation }\end{array}$ \\
\hline Firm size & $\begin{array}{l}\text { Firm size of the acquirers is the natural logarithm of } \\
\text { total assets. }\end{array}$ & Datastream \\
\hline Profitability & $\begin{array}{l}\text { Profitability of the acquirers is the EBITDA divided by } \\
\text { total assets (in total units). }\end{array}$ & Datastream \\
\hline Asset tangibility & $\begin{array}{l}\text { Asset tangibility of the acquirers is the power, plant \& } \\
\text { equipment divided by total assets (in total units). }\end{array}$ & Datastream \\
\hline Cash & $\begin{array}{l}\text { Cash of the acquirers is the total sum of cash and cash } \\
\text { equivalents (in total units). }\end{array}$ & Datastream \\
\hline Public target & $\begin{array}{l}\text { Dummy variable whether the target is public or private. } \\
\text { Takes a value of " } 1 \text { " for public, and " } 0 \text { " for private. }\end{array}$ & Zephyr \\
\hline $\begin{array}{l}\text { Different } \\
\text { industries }\end{array}$ & $\begin{array}{l}\text { Dummy variable whether the acquirer and target operate } \\
\text { cross- or in equal industries. Takes a value of " } 1 \text { " for } \\
\text { cross-industries, and " } 0 \text { " for equal industries. }\end{array}$ & ICB \\
\hline Non-fin./utility & $\begin{array}{l}\text { Indicates whether the acquirer and target are financials } \\
\text { or industries. Takes a value of " } 1 \text { " if the companies are } \\
\text { financials/utilities, and " } 0 \text { " if being non- } \\
\text { financials/utilities. }\end{array}$ & $\begin{array}{l}\text { Authors' } \\
\text { calculation }\end{array}$ \\
\hline Cross-border & 2-digit country code for the acquirer and target & Datastream \\
\hline
\end{tabular}

* The variable in Datastream corrects for both dividends and stock splits. 
The firm specific characteristics consist of several balance sheet indicators such as firm size, asset tangibility, profitability and cash. The last set of control variables refers to country aspects as the legal system in Europe consists of mainly Common Law (United Kingdom/Ireland) and Civil Law (Continental Europe) countries. The variables are described in Table 2 above.

\subsection{Sample distribution}

For most of the 717 deals included in our analysis, the method of payment is cash (560) and the financing source is debt (550) as summarized in Table 3 below. Almost $70 \%$ of the deals are from firms operating in the same industry. The consumer services industry has the highest frequency of deal announcements. Around $85 \%$ of all transactions involve private targets (615). The annual distribution of the deals distinguishing between public and private targets is provided in Figure 1 below.

Table 3. Summary descriptive of deal characteristics

\begin{tabular}{|l|l|}
\hline Method of payment & Obs. \\
\hline Cash & 560 \\
\hline Shares & 157 \\
\hline Financing source & \\
\hline Debt & 550 \\
\hline Equity & 167 \\
\hline Status Targets & \\
\hline Public & 102 \\
\hline Private & 615 \\
\hline
\end{tabular}

The sample distribution per country is provided in Table 4. Evidently, and as always in European studies, deals with United Kingdom firms involved dominate the sample with about $60 \%$ of the bidder and target firms. Deals with companies from other EEA countries are in general quite evenly distributed, with deals from non-EEA countries hardly being present. 
Wolfgang BESSLER, David KRUIZENGA, Wim WESTERMAN

Table 4. Distribution per country

\begin{tabular}{|c|c|c|c|c|c|}
\hline \multicolumn{3}{|c|}{ Acquirer } & \multicolumn{3}{|c|}{ Target } \\
\hline Country & Frequency & Percent & Country & Frequency & Percent \\
\hline Austria & 2 & $0.28 \%$ & Austria & 2 & $0.28 \%$ \\
\hline Belgium & 9 & $1.26 \%$ & Belgium & 10 & $1.39 \%$ \\
\hline Switzerland & 15 & $2.09 \%$ & Switzerland & 13 & $1.81 \%$ \\
\hline Cyprus & 1 & $0.14 \%$ & Cyprus & 1 & $0.14 \%$ \\
\hline Germany & 20 & $2.79 \%$ & Germany & 38 & $5.30 \%$ \\
\hline Denmark & 4 & $0.56 \%$ & Denmark & 9 & $1.26 \%$ \\
\hline Spain & 20 & $2.79 \%$ & Spain & 20 & $2.79 \%$ \\
\hline Finland & 22 & $3.07 \%$ & Finland & 13 & $1.81 \%$ \\
\hline France & 31 & $4.32 \%$ & France & 33 & $4.60 \%$ \\
\hline $\begin{array}{l}\text { United } \\
\text { Kingdom }\end{array}$ & 456 & $63.60 \%$ & United Kingdom & 429 & $59.83 \%$ \\
\hline Greece & 2 & $0.28 \%$ & Croatia & 1 & $0.14 \%$ \\
\hline Croatia & 1 & $0.14 \%$ & Ireland & 11 & $1.53 \%$ \\
\hline Hungary & 1 & $0.14 \%$ & Iceland & 1 & $0.14 \%$ \\
\hline Ireland & 16 & $2.23 \%$ & Italy & 21 & $2.93 \%$ \\
\hline Iceland & 5 & $0.70 \%$ & Luxembourg & 5 & $0.70 \%$ \\
\hline Italy & 19 & $2.65 \%$ & Serbia/Montenegro & 1 & $0.14 \%$ \\
\hline Netherlands & 17 & $2.37 \%$ & Malta & 1 & $0.14 \%$ \\
\hline Norway & 11 & $1.53 \%$ & Netherlands & 34 & $4.74 \%$ \\
\hline Poland & 14 & $1.95 \%$ & Norway & 10 & $1.39 \%$ \\
\hline Russia & 3 & $0.42 \%$ & Poland & 13 & $1.81 \%$ \\
\hline Sweden & 48 & $6.69 \%$ & Portugal & 1 & $0.14 \%$ \\
\hline & & & Romania & 2 & $0.28 \%$ \\
\hline & & & Russia & 3 & $0.42 \%$ \\
\hline & & & Sweden & 44 & $6.14 \%$ \\
\hline & & & Turkey & 1 & $0.14 \%$ \\
\hline Total & 717 & $100 \%$ & Total & 717 & $100 \%$ \\
\hline
\end{tabular}


Figure 1. Distribution of deals over the period 1997-2016

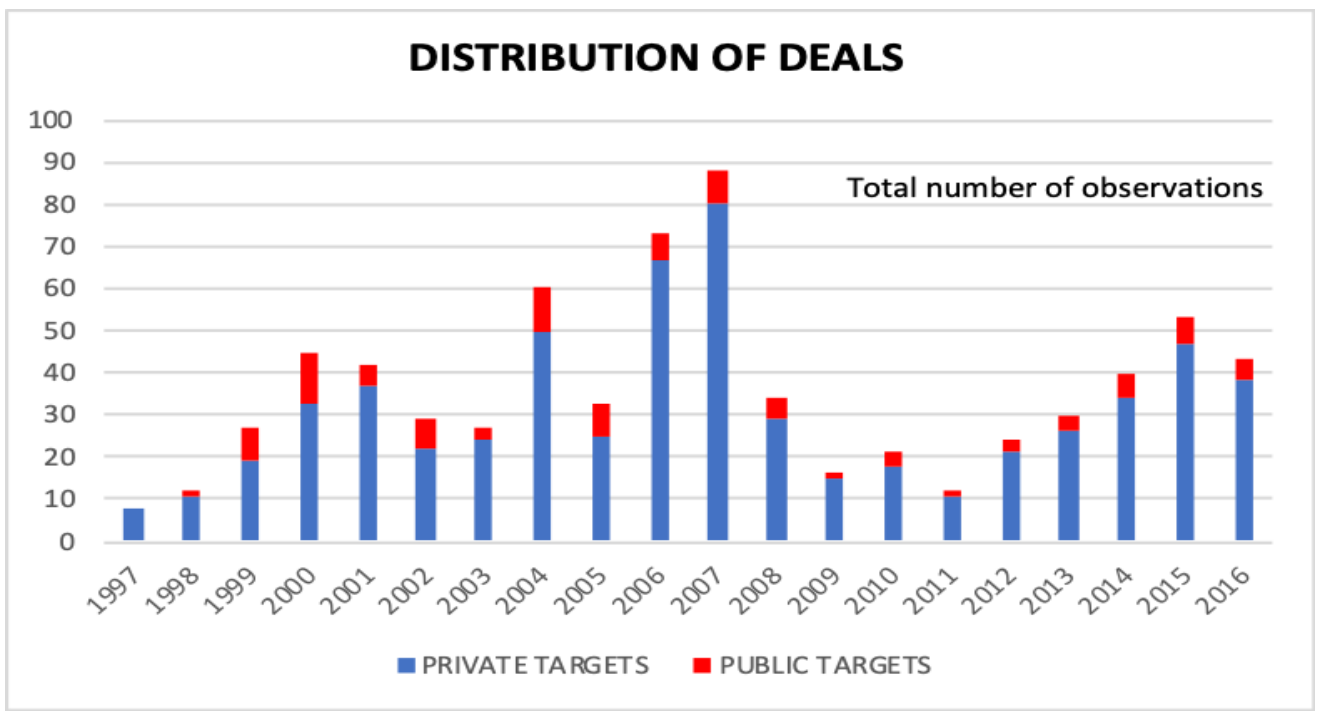

\section{Methodology}

This study focuses on the effects that M\&A related financing and method of payment decisions have on the market value of bidders surrounding the merger announcements. We employ the event study methodologies of MacKinlay (1997) and Brown and Warner (1985) as outlined below (4.1.) to determine the abnormal (AAR) and cumulative abnormal returns (CAAR). The factors that determine the magnitude of the performance and the performance differences are analyzed by using cross-sectional regressions. The structure of these models and the regression equations are explained below (4.2.).

\subsection{Event study methodology}

The standard event study methodologies of MacKinlay (1997) and Brown and Warner (1985) are used to determine the abnormal returns. The abnormal return is the difference between the ex-ante expected return $\left(E\left(R_{i t}\right)\right)$ and the ex-post realized return $\left(\mathrm{R}_{\mathrm{it}}\right)$. A parameter, such as the firm's beta required to calculate the expected 


\section{Wolfgang BESSLER, David KRUIZENGA, Wim WESTERMAN}

returns, is determined over the period (estimation window) prior to the announcement. In this study, we use an estimation window of 201 days covering the period from 260 days prior to 60 prior the event. We exclude the 60 days prior to the announcement to avoid any bias caused by merger rumors (MacKinlay 1997; Fischer 2017).

Models for estimating the expected returns include the constant mean return model and the market model (MacKinlay 1997). We use the latter and adopt the STOXX EUROPE 600 Index for representing the market. This index includes 600 large, medium, and small size capitalized European firms from 17 European countries. Therefore, it represents our data set well, is denominated in the euro currency, and is available for the entire sample period from 1997-2016. To capture the abnormal returns, we choose an event window of 61 days, from 30 days prior to 30 days subsequent to the M\&A announcement. We also analyze alternative event windows within the range $(-30 ;+30)$ to test for additional influences (Martynova, Renneboog 2009). A special focus is on the short-term valuation effects covering the three-day event window surrounding the announcement, which is from one day before to one day after the event $(-1 ;+1)$. All merger related valuation effects should occur during this time window as long as the markets are informationally efficient (Fama 1970). Previous research also suggests that the most statistically reliable evidence whether M\&As create shareholder value is observed in this short-term window (Andrade et al. 2001).

The estimated returns for any given security in the event window are calculated as follows:

(1) $R_{i \tau}=a_{i}+\beta_{i} R_{m t}+\varepsilon_{i t} E\left(\varepsilon_{i t}=0\right) \quad \operatorname{var}\left(\varepsilon_{i t}\right)=\sigma_{s_{i}}^{2}$

$\begin{array}{rll}\text { with } \quad \mathrm{R}_{i t}= & \text { Period t-return on security } \mathrm{i}, \\ \mathrm{R}_{m t}= & \text { Period t-return on the market model, } \\ \alpha_{i}= & \text { Intercept coefficient of the market model, } \\ \beta_{i}= & \text { Slope coefficient of the market model, } \\ \varepsilon_{i t}= & \text { Zero mean disturbance term. }\end{array}$

The abnormal return $\mathrm{AR}_{\mathrm{it}}$ is calculated as the difference between the ex-ante expected return $E\left(R_{i t}\right)$ and the ex-post realized return $A_{i t}$ for any given security: 
(2) $A R_{i t}=R_{i t}-\mathrm{E}\left(R_{i t}\right)$

with $\mathrm{AR}_{i t}=$ Abnormal return in period t on security $\mathrm{i}$,

$R_{i t}=$ Actual return in period $t$ on security $i$,

$\mathrm{E}\left(\mathrm{R}_{i \mathrm{it}}\right)=\quad$ Expected return in period $\mathrm{t}$ on security $\mathrm{i}$.

For different event windows the abnormal returns are summed to cumulative average abnormal returns (CAAR). The CAAR are calculated as follows:

(3) $C A A R_{t}=\sum_{t=1}^{t=-1} A A R_{t}$

The calculation of the T-statistic is shown below:

(4) T S tat $=$ CAARt / $\left(\frac{\text { CAARt }}{\sqrt{N-1}}\right)$

We test for the influences of different variables on the magnitude of the valuation effects by employing the cumulative average abnormal returns (CAARs) as the dependent variables in our regression analyses. Thereby, a range of independent variables - continuous, categorical, and indicator variables - are used to explain the size of the valuation effects and for testing multiple hypotheses. The equation is displayed below:

(5) CAAR $_{t}=\alpha_{i}+\beta_{1}$ Financing source $+\beta_{2}$ Payment method $+\beta_{3} \mathrm{M} / \mathrm{B}+$ $\beta_{4}$ Transaction value $+\beta_{5}$ Cash $+\beta_{6}$ Firm size $+\beta_{7}$ Profitability $+\beta_{8}$ Asset tangibility + $\beta_{9}$ Different industries $+\beta_{10}$ Cross-border $+\beta_{11}$ Public target $+\beta_{12}$ Non-fin./utility

All independent variables were previously defined in Table 2 .

\subsection{Research models}

The explanatory power that different variables have in explaining the valuation effects (abnormal returns) of the acquirer are analyzed with single and multiple regression models. We employ two types of linear regression models, whereby attention should be paid not only to the significance of the coefficients, but most importantly to the interpretations of the model and to the regression output. First, the 


\section{Wolfgang BESSLER, David KRUIZENGA, Wim WESTERMAN}

financing sources regressions are detailed. The first equation is related to the first hypothesis $(\mathrm{Hl})$ and investigates the impact that debt and equity financing have on explaining the cumulative abnormal returns of acquirers. Since the variable contains a dummy indicator, one could only choose debt or equity as financing source.

(6) $C A A R_{t}=\alpha_{i}+\beta_{1}$ Financing source

The regression model includes multiple explanatory variables that tests for the effects of each variable on the abnormal returns. See Eq. 8 for the mathematical representation:

(7) $C A A R_{t}=\alpha_{i}+\beta_{1}$ Financing source $+\beta n$ (Explanatory variables)

To analyze whether the group of explanatory variables influences transactions that are financed with debt or equity differently, the regression model should be transformed and the interpretation changed. Eq. 9 exhibits the single regressions of debt or equity on the abnormal returns. Since other variables might explain the model, the outcome is coherent with the one of Eq. 7.

\section{(8) $C A A R_{t} \mid$ Debt or Equity $=\alpha_{i}$}

However, if we extend the model to a multiple regression model, the economic explanation is considerable different than the regression model illustrated by Eq. 8 . Eq. 10 displays the mathematical description if we extend the regression model to include multiple explanatory variables. Consequently, the explanatory variables measure the impact on the abnormal returns that are financed with debt or equity.

(9) $C A A R_{t} \mid$ Debt or Equity $=\alpha_{i}+\beta \mathrm{n}$ (Explanatory variables)

In addition, supplementary tests are performed to verify the validity of the regression process and results. First, the multiple regressions are executed on robust standard errors (White standard errors), where heteroskedastic residuals are applied in the model. The procedure was introduced by Huber (1967) and further developed by White (1980). Next, the Mann-Whitney test is used to compare the different values of multiple populations. The Mann-Whitney test (or Wilcoxon rank-sum test) 
is a non-parametric test that compares the populations, whether one sample will be significantly less than or greater than a randomly selected value of the other sample (Wilcoxon 1945; Mann, Whitney 1947). Finally, the ordinary Student's t-test assumes that two populations have normal distributions with equal variances, but the Welch's t-test is depicted for different size and unequal variance samples to analyze differences in means (Welch 1947). The Welch's t-test provides more robust results than the normal Student's t-test according to Rasch, Teuscher and Guiard (2007).

Since the sample size of targets is rather low, the Mann-Whitney test and Welch's t-test are performed on the targets' mean populations. Regression analyses on a few observations may lead to highly inaccurate parameters and biased estimates (Potter 2005; Maiti, Pradhan 2009). Therefore, we apply mean comparison tests to prevent inaccurate outcomes.

\section{Results}

In this section, we present and discuss the empirical results of our study. Section 5.1. contains the analyses of the valuation effects. We first test whether mergers create value for the shareholders of bidder and target firms around the announcement dates. As preliminary evidence, we also graph the abnormal and cumulative abnormal returns to depict the structure of the daily abnormal returns and the cumulative abnormal return over the entire event window. In section 5.2. we present our analyses for the bidder firms, which includes the tests of the three hypotheses - H1, $\mathrm{H} 2 a, H 2 b$ - and additional tests. For every hypothesis, we present and discuss the single and multiple regression results. In addition, we investigate how the explanatory variables determine the abnormal returns. For this we control for population groups. Subsequently, robust standard errors are used for the multiple regression models and the Mann-Whitney test is performed to compare the population means. In section 5.3. we present the tests for the targets. 


\section{Wolfgang BESSLER, David KRUIZENGA, Wim WESTERMAN}

\subsection{Valuation effects}

In Table 5 we present the sample t-test of the abnormal returns over different event windows. The abnormal returns for the targets are for most event windows significantly different from zero at the one percent level (Panel B). Consequently, target shareholders benefit the most from merger announcements, which is consistent with findings of Goergen and Renneboog (2004) and Martynova and Renneboog (2009) and the literature, implying that mergers create substantial wealth for target shareholders. Interpreted from a different perspective, the shareholders of the target are only willing to surrender their shares to the bidder when they are compensated by a substantial premium, i.e. by receiving a significantly higher price than the current share price. To provide a detailed presentation, we analyze different event windows around, before, and subsequent to the announcement.

For the four windows around the event $(-30 ;+30) ;(-10 ;+10) ;(-3 ;+3) ;(-1 ;+1)$, we observe significantly positive abnormal target returns of $27.08 \%, 19.99 \%$, $17.03 \%$, and $15.40 \%$, respectively, and $11.99 \%$ at the event day, indicating a significant and substantial increase in target share prices. Surprisingly, the abnormal return in the periods before $(-10 ;-1)$ and subsequent $(+1 ;+10)$ to the announcement are also significant with $5.71 \%$, and $2.29 \%$, respectively. These results are clearly visible in Figures $2 \mathrm{a}$ and $2 \mathrm{~b}$, at least for the period before the public announcement and for the event day. For the pre-merger period, we observe a substantial and significant run-up, which seems surprising but is explainable by the fact that our sample contains mainly private targets. The results for private targets and the size of the mark-up at the event date is similar to other studies.

Next, we calculate the (cumulative) abnormal returns for bidder firms and observe some positive valuation affects for the periods surrounding the event. A significant increase in the stock prices is found, which means that the market reacts positively to the announcements. However, these positive abnormal returns are mainly due to the significant announcement returns $(0 ;+1)$. It appears that there is no leakage of information in the period $(-10 ;-1)$ before the announcement date for acquirers as the CARs are insignificantly different from zero. Whether the market reacts slowly to the merger announcement or has difficulties in correctly valuing the deal is covered by the $(+1 ;+10)$ interval window. For the period subsequent the 
announcement, there is only a marginal increase revealed, suggesting that the information is fully absorbed at the announcement. Therefore, significant valuation effects occur only on the days $(0 ;+1)$ and there are no substantial and significant stock price reactions afterwards. This is consistent with other studies, for example, by Goergen and Renneboog (2004), Martynova and Renneboog (2009) and Alexandris et al. (2010). This is also consistent with the Efficient Market Hypothesis (Fama 1970), which implies that new information is immediately and fully reflected in stock prices and shareholders cannot capture abnormal returns subsequent to an information release.

Other unreported results suggest that the acquirers from Continental Europe achieve, on average, higher mean returns $(1.94 \%)$ than their counterparts from the United Kingdom (1.65\%). Financial and utility companies that expand their business by acquisitions score lower $(0.26 \%)$ than non-financials and non-utilities $(1.95 \%)$. In addition, bidders that acquire public targets have, on average, a negative mean return $(-0.92 \%)$ around the announcement date. This empirical finding is consistent with most of the literature and highlights again that our overall results are primarily determined by the acquisition of private targets, which reveal mean returns of $2.16 \%$. This is significantly different from public targets, and the argument is that shareholders' confidence in the success from acquiring private targets is considerably higher than when acquiring public targets. Furthermore, targets from the United Kingdom perform, on average, better (13.08\%) than firms from Continental Europe (10.29\%). 
Table 5. One sample t-test of the cumulative abnormal returns

\begin{tabular}{|c|c|c|c|c|c|c|c|c|c|c|c|c|c|c|c|c|}
\hline \multicolumn{17}{|l|}{ Panel A } \\
\hline Acquirer & $\begin{array}{r}{[-} \\
30,30]\end{array}$ & & $\begin{array}{r}{[-} \\
10,10]\end{array}$ & & {$[-3,3]$} & & {$[-1,1]$} & & [0] & & $\begin{array}{r}{[-10,-} \\
1]\end{array}$ & & {$[1,10]$} & & {$[0,5]$} & \\
\hline Mean & 0.0296 & & 0.0337 & & 0.0312 & & 0.0271 & & 0.0173 & & 0.0031 & & 0.0116 & & 0.0311 & \\
\hline T-stat & 3.663 & & 6.984 & & 9.465 & & 9.978 & & 8.770 & & 1.090 & & 3.803 & & 9.462 & \\
\hline P-value & 0.0001 & $* * *$ & 0.0000 & $* * *$ & 0.0000 & $* * *$ & 0.0000 & $* * *$ & 0.0000 & $* * *$ & 0.1378 & & 0.0001 & $* * *$ & 0.0000 & $* * *$ \\
\hline \multicolumn{17}{|l|}{ Panel B } \\
\hline Target & $\begin{array}{r}{[-} \\
30,30]\end{array}$ & & $\begin{array}{r}{[-} \\
10,10]\end{array}$ & & {$[-3,3]$} & & {$[-1,1]$} & & [0] & & $\begin{array}{r}{[-10,-} \\
1]\end{array}$ & & {$[1,10]$} & & {$[0,5]$} & \\
\hline Mean & 0.2708 & & 0.1999 & & 0.1703 & & 0.1540 & & 0.1199 & & 0.0571 & & 0.0229 & & 0.1425 & \\
\hline T-stat & 8.565 & & 8.629 & & 8.479 & & 7.706 & & 6.574 & & 4.555 & & 2.331 & & 7.366 & \\
\hline P-value & 0.0000 & $* * *$ & 0.0000 & $* * *$ & 0.0000 & $* * *$ & 0.0000 & $* * *$ & 0.0000 & $* * *$ & 0.0000 & $* * *$ & 0.0110 & $* *$ & 0.0000 & $* * *$ \\
\hline
\end{tabular}

Table 5 presents the cumulative average abnormal returns (CAAR) of the sample of acquirers and targets. The number of observations are respectively 717 and 92 . Per event window is the mean, $t$-statistic and p-value given. The values are winsorized at the lower $1 \%$ and upper $99 \%$. The significance levels are: ***,*** which stands for $10 \%, 5 \%$, and the $1 \%$ level. 
Figure 2a. Cumulative Abnormal Returns of the acquirers and targets

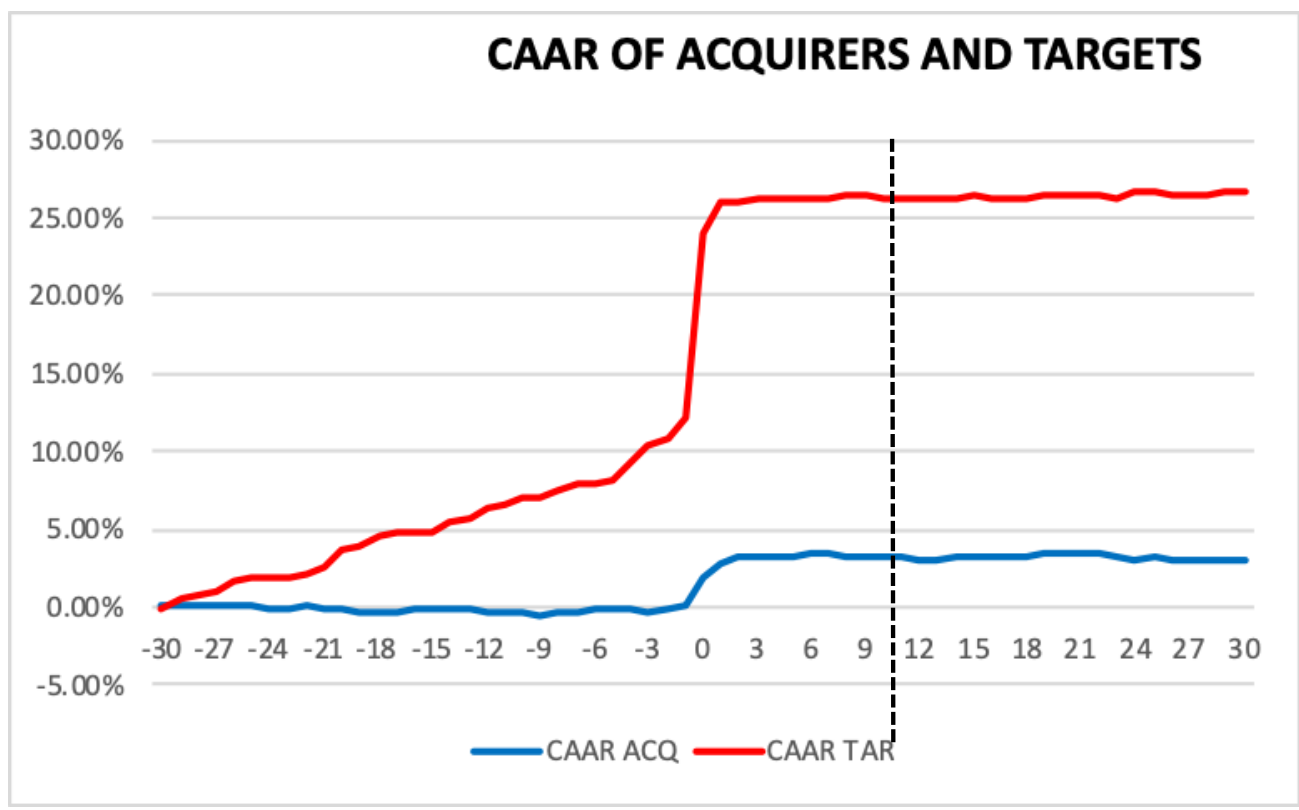

Figure 2b. Abnormal Returns of the acquirers and targets

\section{AAR OF ACQUIRERS AND TARGETS}

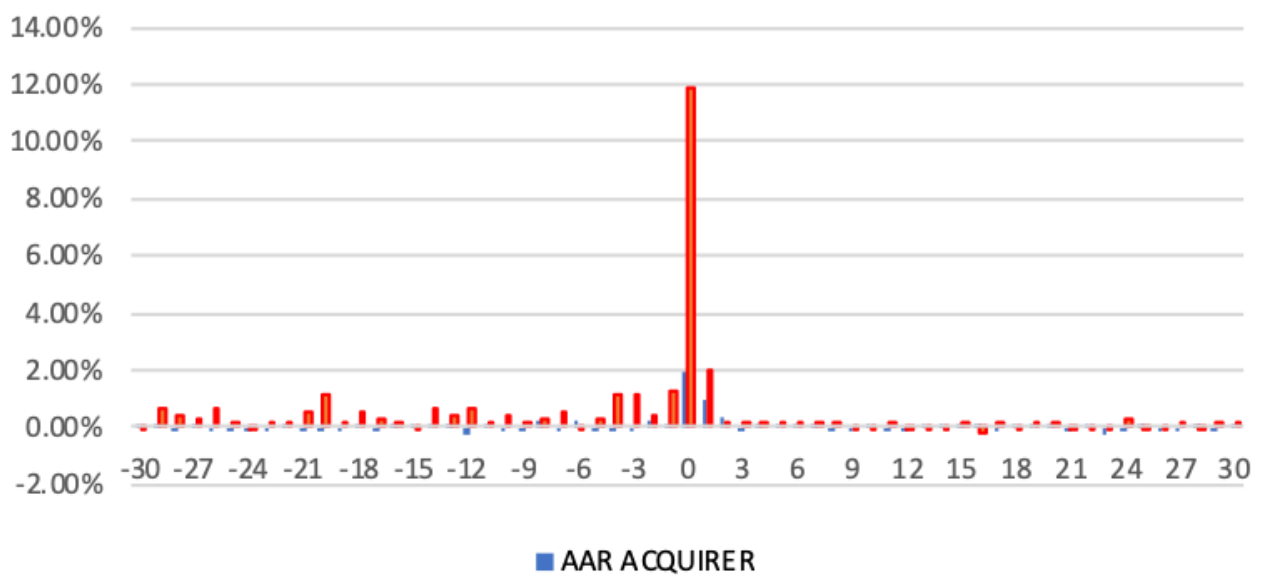

Number of observations targets $=92$.

Number of observations acquirers $=717$. 


\section{Wolfgang BESSLER, David KRUIZENGA, Wim WESTERMAN}

\subsection{Acquirers: cross-sectional regression analysis}

We start our analysis of the factors determining the magnitude of the abnormal announcement returns of bidders in section 5.2.1., with a focus on the two alternative financing sources debt and equity. The effects of the method of payment on the size of the abnormal announcement returns are investigated in section 5.2.2.

\subsubsection{Financing sources}

In Table 6, we display the cumulative abnormal returns for the bidder sample. Mean and median values are given for equity, debt and total financing for different event windows. Overall, firms using debt to finance their mergers have considerably higher returns than those issuing new equity. The argument is that management would usually finance good projects with debt, to keep the benefits for themselves, but problematic projects with equity to share the risks and possible losses with the new shareholders. This result suggests that the management of the bidder is able to signal the higher quality of the acquisition by selecting the appropriate financing source. This signal seems to be interpreted accordingly by market participants in that the abnormal returns at the event day $(0)$ and around the announcement date $(-1 ;+1)$ for debt $(1.85 \%$ and $2.90 \%)$ are higher than for equity (1.29\% and $2.09 \%)$. For larger windows $(-3 ;+3$ and $-10 ;+10)$ not only the abnormal returns increase for debt $(3.47 \%$ and $3.75 \%)$ and equity $(1.97 \%$ and $2.07 \%)$ financing, but also the differences widens. We observe the largest return difference between debt and equity financing for the $(-10 ;+10)$ event window with $1.68 \%(3.75 \%-2.07 \%)$. All of this is consistent with the previous literature and the findings of Martynova and Renneboog (2009) and Fischer (2017), suggesting that debt is the preferred financing source for value generating acquisitions.

The important question, however, is whether the means of equity and debt financing are significantly different. For this we perform the Mann-Whitney test. The results are displayed in Table 7 by providing the Z-score and P-value for the corresponding event windows. Additionally, the tests are also performed for the announcement date (day 0 ). The means of debt and equity financing are statistically different from zero in the short run. The Z-score at the announcement date is 2.083, which has a significance level of 5\%, compared to the Z-score on the three-day 
interval $(-1,+1$ days) of 1.737 and a corresponding significance level of $10 \%$. The Mann-Whitney test implies that the population mean of debt financing is higher than the mean of equity financing at the merger announcement, which indicates an outperformance and strongly support our signalling argument of debt financing. We therefore provide evidence in support of our first Hypothesis (1), that debt financed deals outperform share financed deals at least in the short run.

Table 6. Cumulative abnormal returns of financing

\begin{tabular}{|c|c|c|c|c|c|}
\hline & {$[-10,+10]$} & {$[-3,+3]$} & {$[-1,+1]$} & [0] & Obs. \\
\hline \multirow[t]{2}{*}{ Equity } & 0.0207 & 0.0197 & 0.0209 & 0.0129 & \multirow[t]{2}{*}{167} \\
\hline & $(0.0158)$ & $(0.0078)$ & $(0.0096)$ & $(0.0084)$ & \\
\hline \multirow[t]{2}{*}{ Debt } & 0.0375 & 0.0347 & 0.0290 & 0.0185 & \multirow[t]{2}{*}{550} \\
\hline & $(0.0236)$ & $(0.0255)$ & $(0.0196)$ & $(0.0061)$ & \\
\hline \multirow[t]{2}{*}{ Total } & 0.0336 & 0.0312 & 0.0271 & 0.0172 & \multirow[t]{2}{*}{717} \\
\hline & $(0.0214)$ & $(0.0208)$ & $(0.0154)$ & $(0.0044)$ & \\
\hline
\end{tabular}

Table 7. Two sample Mann-Whitney test - financing determinants

\begin{tabular}{|l|l|l|l|}
\hline & Z-score & P-value & \\
\hline AR [0] & 2.083 & 0.0372 & $* *$ \\
\hline CAR $[-1 ;+1]$ & 1.737 & 0.0824 & $*$ \\
\hline CAR $[-10 ;+10]$ & 0.865 & 0.3872 & \\
\hline $\begin{array}{l}\text { Table } 7 \text { shows the Mann-Whitney test by comparing the means of the financing } \\
\text { determinants. The columns present the Z-score and P-value. The significance levels are: } \\
*, * * * * * \text { for } 10 \%, 5 \%, \text { and the } 1 \% \text { level. }\end{array}$ \\
\hline
\end{tabular}

The graphical presentation in Figures $3 \mathrm{a}$ and $3 \mathrm{~b}$ support our expectations and findings so far. For debt financing there is no valuation effect before the 
announcement, a substantial announcement effect around the event of about 4\%, and hardly any stock price reaction subsequently. For equity financing we observe a different picture, which, however, we already detected by analyzing the abnormal returns in Table 6 . Over the pre-announcement period, the abnormal returns cumulate to a negative return of about $2 \%$ and then react positively at the announcement day (3\%), resulting in an overall valuation effect of about $1 \%$ as there is not further stock price reaction subsequently. Overall financing a deal with debt instead of equity results in a three percentage points higher positive valuation effect for the bidder firm as debt financing may signal managements' confidence in the quality and success of the merger or acquisition.

\section{Figure 3a. Cumulative abnormal returns of financing sources}

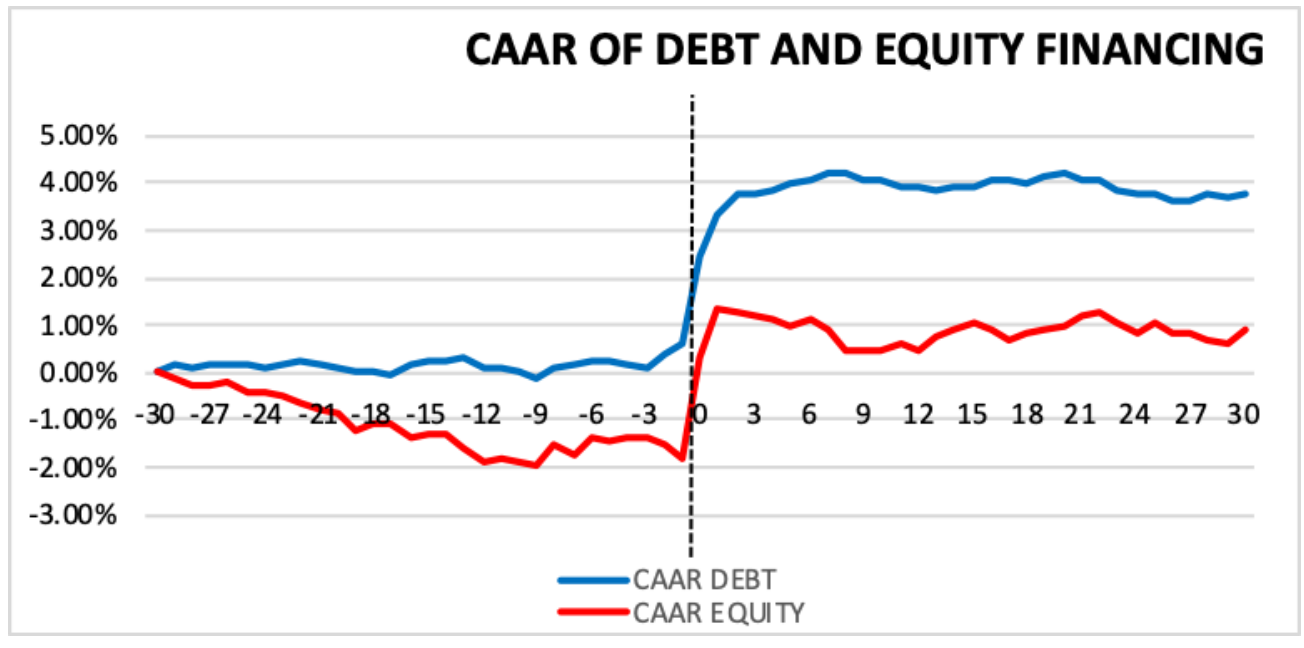

In Table 8 we present the results of the single (Models 1 and 4) and multiple regressions (Models 2, 3, and 5, 6) for six different model specifications. The objective is to analyse the effects of multiple explanatory variables on the cumulative abnormal returns for different event windows. Models 1-3 contain the regressions for the longer window $(-10,+10)$, and models $4-6$ analyse the impact around the shorter announcement period $(-1,+1)$. The main independent variable is Debt or Equity, and the model employs the following control variables: Transaction 
Value, Cash, Market-to-Book-ratio, Firm Size, Profitability, and Asset Tangibility, followed by dummies that control for different industries, non-financials/utilities, public targets, and cross-border takeovers.

Figure 3b. Abnormal returns of financing sources

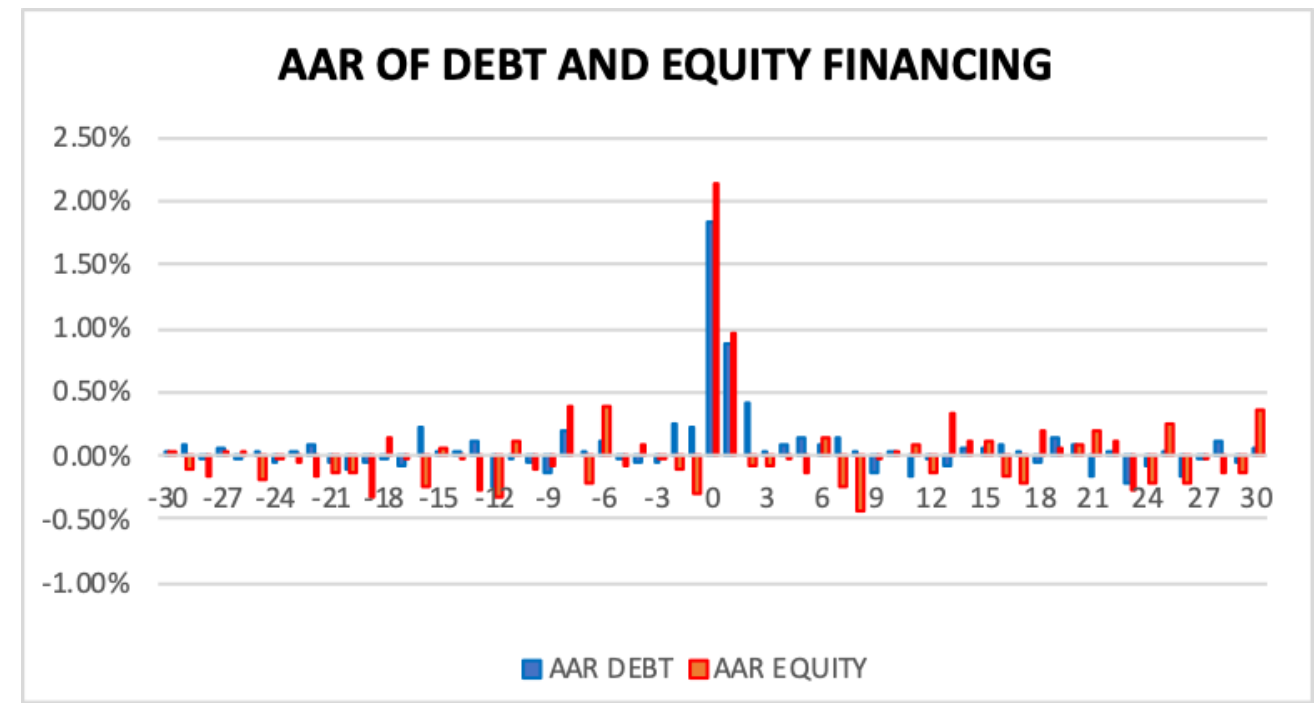

Debt - number of observations $=550$.

Equity - number of observations $=167$.

For the single regression models (first column Table 8), we implement the following approach, which can be illustrated as follows:

(10) $C A A R_{t}$ Equity $=0.0207+0.0168 *$ Debt

(11) $C A A R_{t}$ Debt $=0.0375-0.0168 *$ Equity

This pattern occurs since the financing source is a binary variable, which takes the value of " 0 " or " 1 ", because, if a company uses equity, it cannot choose debt as its financing source and vice-versa. Therefore, one single regression model suffices 


\section{Wolfgang BESSLER, David KRUIZENGA, Wim WESTERMAN}

to investigate the effect of the financing sources on the magnitude of CAARs. The pattern holds for other single regression models.

In the single regression Model 1 for the longer window $(-10 ;+10)$, the intercept (2.07\%) presents the CAARs when a company finances the merger with equity. This coefficient is significantly different from zero at the 5\% level, holding other variables constant. When the merger is financed with debt, the abnormal returns increases by $1.68 \%$ to the level of $3.75 \%$. For the shorter event window $(-1 ;+1)$, the corresponding figures are an intercept of $2.09 \%$, representing equity financing, and an increase for debt financing by $0.809 \%$ to overall abnormal returns of $2.90 \%$. Both coefficient for debt financing are positive but insignificant, although previous evidence suggests that debt financing has a significantly positive effect. Overall, the results suggest that there is some economic support for the argument that debt financing should generate a positive and higher valuation effect (albeit insignificant), which is consisted with our previous results and the conclusions by Martynova and Renneboog (2009).

The results from the multiple regression models in Table 8 reveal some interesting insights and support our previous evidence. Most importantly, we observe a significant difference between public and private targets in all models. The target's status is represented by the public target dummy. Shareholder confidence in the success of acquiring public targets is considerably lower than the confidence when acquiring private targets. The effects of public targets on the abnormal returns are $-5.14 \%(-10 ;+10)$ and $-3.64 \%(-1 ;+1)$. Since the public targets contain a binary variable, the private targets provide opposite results. The decreasing rate of returns of public targets is substantial, although one should consider that this impact only plays a role if the other variables are held constant. Nevertheless, the results confirm our conjecture that our previously observed positive abnormal bidder returns at the announcement date are mostly due to private targets.

In Models 2 and 3 for the 21-day event window surrounding the event (-10; +10 ), we observe that the market-to-book-ratio has a substantial and significantly negative effect $(-0.00461)$ on the CAARs. This implies that if, for example, a companies' market-to-book-ratio increases from two to three, the abnormal returns decreases by $0.461 \%$. Profitability also affects the abnormal returns significantly 
negative (-0.00130), but Asset Tangibility has a significantly positive impact $(0.000814)$. For the shorter event window $(-1 ;+1)$, we observe a negative size-effect $(-0.00989)$, suggesting that larger firms experience lower abnormal returns at the announcement (Table 8). Although these results are significant, they seem to be relative small in economic terms, which might be due to the short event windows that we apply.

In Table 9 we provide the regression models for alternative financing sources, analysing the impact that various explanatory variables have on the size of the CAARs of debt and equity financing. We employ single (models 1, 2, 5, 6) and multiple (models 3, 4, 7, 8) regression models. Models 1-4 cover the longer windows $(-10 ;+10)$, and the models $5-8$ the shorter windows $(-1 ;+1)$. The regression includes the following control variables: Transaction Value, Cash, Market-to-Book-Ratio, Firm Size, Profitability and Asset Tangibility. Dummies control for different industries, non-financials/utilities, public targets, and crossborder takeovers.

The results provide the effect of the explanatory variables on the abnormal returns of debt or equity financing (see Eq. 10). Debt financing significantly outperforms equity financing, which is consistent with most of the literature and with Martynova and Renneboog (2009). The differences are 1.69\% and $0.81 \%$ for the event windows of 21 days and three days around the merger announcement, respectively. Model 7 reveals that the coefficient of debt financing is statistically significant at the $1 \%$ level, implying that the abnormal returns of debt financing in the short-term window could rise to $12.5 \%$. The dependent variable is measured as cumulative percentages, so considerable high returns are economically important. Interestingly, we find for public targets that there is a negative effect on the abnormal returns for both debt and equity financing, which is in accordance with Martynova and Renneboog (2009) and Fischer (2017). 
Wolfgang BESSLER, David KRUIZENGA, Wim WESTERMAN

Table 8. Single and multiple regression of cumulative abnormal returns

\begin{tabular}{|c|c|c|c|c|c|c|}
\hline Model & 1 & 2 & 3 & 4 & 5 & 6 \\
\hline $\begin{array}{l}\text { Variables } \\
\text { Periods }\end{array}$ & $(-10 ;+10)$ & $(10 ;+10)$ & $(10 ;+10)$ & $(-1 ;+1)$ & $(-1 ;+1)$ & $(-1 ;+1)$ \\
\hline \multirow[t]{2}{*}{ Constant } & $0.0207 * *$ & 0.00277 & 0.00277 & $0.0209 * * *$ & $0.103 * * *$ & $0.103 * * *$ \\
\hline & (0.00998) & $(0.0664)$ & $(0.0612)$ & $(0.00563)$ & $(0.0380)$ & $(0.0351)$ \\
\hline \multirow[t]{2}{*}{ Debt } & 0.0168 & 0.0105 & 0.0105 & 0.00809 & 0.0102 & 0.0102 \\
\hline & $(0.0114)$ & $(0.0118)$ & $(0.0114)$ & $(0.00643)$ & $(0.00673)$ & $(0.00673)$ \\
\hline \multirow[t]{2}{*}{ Transaction V. } & & -0.0000 & -0.0000 & & -0.0000 & -0.0000 \\
\hline & & $(0.0000)$ & $(0.0000)$ & & $(0.0000)$ & $(0.0000)$ \\
\hline \multirow[t]{2}{*}{ Cash } & & $-0.0000^{*}$ & $-0.0000^{*}$ & & 0.0000 & 0.0000 \\
\hline & & $(0.0000)$ & $(0.0000)$ & & $(0.0000)$ & $(0.0000)$ \\
\hline \multirow[t]{2}{*}{$\mathrm{MB}$} & & $-0.00461 * * *$ & $\begin{array}{l}- \\
0.00461 * * *\end{array}$ & & -0.000595 & -0.000595 \\
\hline & & $(0.00140)$ & $(0.00159)$ & & $(0.000803)$ & $(0.000860)$ \\
\hline \multirow[t]{2}{*}{ Firm size } & & 0.000501 & 0.000501 & & $-0.00989 * *$ & $\begin{array}{l}- \\
0.00989 * * *\end{array}$ \\
\hline & & $(0.00736)$ & $(0.00683)$ & & $(0.00421)$ & $(0.00381)$ \\
\hline \multirow[t]{2}{*}{ Profitability } & & $-0.00130 * * *$ & $-0.00130 * *$ & & -0.000214 & -0.000214 \\
\hline & & $(0.000495)$ & $(0.000578)$ & & $(0.000284)$ & $(0.000307)$ \\
\hline $\begin{array}{l}\text { Asset } \\
\text { tangibility }\end{array}$ & & $\begin{array}{l}0.000814 * * * \\
(0.000218)\end{array}$ & $\begin{array}{l}0.000814 * * \\
(0.000237)\end{array}$ & & $\begin{array}{c}0.000191 \\
(0.000125)\end{array}$ & $\begin{array}{c}0.000191 \\
(0.000129)\end{array}$ \\
\hline $\begin{array}{l}\text { Different } \\
\text { industry }\end{array}$ & & $\begin{array}{c}0.0192 * \\
(0.0104)\end{array}$ & $\begin{array}{c}0.0192 * \\
(0.0100)\end{array}$ & & $\begin{array}{l}-0.000253 \\
(0.00595)\end{array}$ & $\begin{array}{l}-0.000253 \\
(0.00587)\end{array}$ \\
\hline \multirow[t]{2}{*}{ Non-fin./utility } & & $0.0310 * *$ & $0.0310 * *$ & & 0.00649 & 0.00649 \\
\hline & & $(0.0154)$ & $(0.0128)$ & & $(0.00881)$ & $(0.00751)$ \\
\hline \multirow[t]{2}{*}{ Public target } & & $-0.0514 * * *$ & $-0.0514 * * *$ & & $-0.0364 * * *$ & $-0.0364 * * *$ \\
\hline & & $(0.0147)$ & $(0.0131)$ & & $(0.00840)$ & $(0.00805)$ \\
\hline \multirow[t]{2}{*}{ Cross-border } & & -0.00614 & -0.00614 & & 0.00137 & 0.00137 \\
\hline & & $(0.0119)$ & $(0.0121)$ & & $(0.00683)$ & $(0.00658)$ \\
\hline Robust & No & No & Yes & No & No & Yes \\
\hline Observations & 717 & 615 & 615 & 717 & 615 & 615 \\
\hline R-squared & 0.003 & 0.078 & 0.078 & 0.002 & 0.080 & 0.080 \\
\hline
\end{tabular}

Figures in parentheses are the (robust) standard errors. The values are winsorized at the lower $1 \%$ and upper $99 \%$. The significance levels are *, **, ***, which stands for $10 \%, 5 \%$, and the $1 \%$ level 
Table 9. Single and multiple regression of the effects on debt and equity financing

\begin{tabular}{|c|c|c|c|c|c|c|c|c|}
\hline Model & 1 & 2 & 3 & 4 & 5 & 6 & 7 & 8 \\
\hline Financing Source & Debt & Equity & Debt & Equity & Debt & Equity & Debt & Equity \\
\hline Variables / Periods & $(-10 ;+10)$ & $(-10 ;+10)$ & $(-10 ;+10)$ & $(-10 ;+10)$ & $(-1 ;+1)$ & $(-1 ;+1)$ & $(-1 ;+1)$ & $(-1 ;+1)$ \\
\hline \multirow{2}{*}{ Constant } & $0.0375 * * *$ & $0.0207 * *$ & 0.0750 & -0.120 & $0.0290 * * *$ & $0.0209 * * *$ & $0.125 * * *$ & 0.0807 \\
\hline & $(0.00558)$ & $(0.00948)$ & $(0.0790)$ & $(0.0998)$ & $(0.00309)$ & $(0.00573)$ & $(0.0427)$ & $(0.0620)$ \\
\hline \multirow[t]{2}{*}{ Transaction V. } & & & -0.0000 & 0.0000 & & & -0.0000 & $0.0000 * * *$ \\
\hline & & & $(0.0000)$ & $(0.0000)$ & & & $(0.0000)$ & $(0.0000)$ \\
\hline \multirow[t]{2}{*}{ Cash } & & & -0.0000 & $-5.95 \mathrm{e}-11 * * *$ & & & 0.0000 & 0.0000 \\
\hline & & & $(0.0000)$ & $(0.0000)$ & & & $(0.0000)$ & $(0.0000)$ \\
\hline \multirow[t]{2}{*}{$\mathrm{MB}$} & & & $-0.00530 * * *$ & -0.00405 & & & -0.000769 & -0.000795 \\
\hline & & & $(0.00204)$ & $(0.00265)$ & & & $(0.00118)$ & $(0.000982)$ \\
\hline \multirow[t]{2}{*}{ Firm size } & & & -0.00576 & 0.0150 & & & $-0.0106 * *$ & -0.00854 \\
\hline & & & $(0.00850)$ & $(0.0119)$ & & & $(0.00453)$ & $(0.00710)$ \\
\hline \multirow[t]{2}{*}{ Profitability } & & & $-0.00125^{* *} *$ & 0.000186 & & & -0.000180 & 0.000444 \\
\hline & & & $(0.000625)$ & $(0.00123)$ & & & $(0.000319)$ & $(0.000882)$ \\
\hline \multirow[t]{2}{*}{ Asset tangibility } & & & $0.000648 * *$ & $0.00121 * * *$ & & & $9.39 \mathrm{e}-05$ & $0.000509 * * *$ \\
\hline & & & $(0.000275)$ & $(0.000262)$ & & & $(0.000144)$ & $(0.000150)$ \\
\hline \multirow[t]{2}{*}{ Different industry } & & & $0.0236^{* *}$ & 0.0112 & & & 0.00288 & -0.0115 \\
\hline & & & $(0.0116)$ & $(0.0197)$ & & & $(0.00684)$ & $(0.0119)$ \\
\hline \multirow[t]{2}{*}{ Non fin./utility } & & & 0.0170 & $0.0514 * * *$ & & & 0.000269 & $0.0218 *$ \\
\hline & & & $(0.0174)$ & $(0.0196)$ & & & $(0.00978)$ & $(0.0128)$ \\
\hline \multirow[t]{2}{*}{ Public target } & & & $-0.0421 * * *$ & $-0.0813 * * *$ & & & $-0.0352 * * *$ & $-0.0370 * *$ \\
\hline & & & $(0.0154)$ & $(0.0265)$ & & & $(0.00908)$ & $(0.0176)$ \\
\hline \multirow[t]{2}{*}{ Cross-border } & & & -0.00117 & -0.0408 & & & 0.00256 & -0.00242 \\
\hline & & & $(0.0137)$ & $(0.0298)$ & & & $(0.00754)$ & $(0.0138)$ \\
\hline Robust & No & No & Yes & Yes & No & No & Yes & Yes \\
\hline Observations & 550 & 167 & 470 & 145 & 550 & 167 & 470 & 145 \\
\hline R-squared & 0.000 & 0.000 & 0.065 & 0.212 & 0.000 & 0.000 & 0.081 & 0.150 \\
\hline
\end{tabular}

Figures in parentheses are the (robust) standard errors. The values are winsorized at the lower $1 \%$ and upper $99 \%$. The significance levels are $*, * * * * *$, which stands for $10 \%, 5 \%$, and the $1 \%$ level 
This may indicate that bidder shareholders are aware of the risks of taking over a listed company. Alternatively, the value of the target is more precisely known in these deals and the target shareholders are successful in demanding a higher premium before tendering their shares. Consequently, our overall findings are determined by the private targets, which may receive, on average, a smaller premium, creating value for the shareholders of the bidder.

\subsubsection{Payment methods}

The second important factor that may influence the magnitude of the valuation effects are the methods of payment. In Table 10 and Figures $4 \mathrm{a}$ and $4 \mathrm{~b}$, we display the cumulative abnormal returns for the bidder over different event windows. The windows cover the mean and median abnormal returns for cash, stock and total payments. Companies that employ cash as a method of payment for their corporate takeovers experience considerably higher returns around the merger announcement than those that pay for the deal with their own shares.

We also test whether the means of cash and share payments are significantly different from each other. For this we perform the Mann-Whitney test. The results are displayed in Table 11 by providing the Z-score and P-value for the corresponding event windows. The tests are also performed for the announcement date (day 0 ). The means of cash and share payments are statistically different from each other at the announcement date. The Z-score at the announcement date is 1.713 and the corresponding P-value is 0.0867 . Therefore, with a $10 \%$ significance level we can state that the population means of cash and share payments differ significantly and that the population mean of cash significantly outperforms the share mean around the announcement. However, the Z-score for the three-day interval $(-1,+1$ days) of 1.292 is insignificant. The Z-score for the 21-day interval ($10,+10$ days) is close to zero and insignificant. Consequently, the results from the Mann-Whitney test imply that the population mean of cash payments is higher than the mean of share payments at the merger announcement, indicating an outperformance. We therefore provide evidence in support of our Hypothesis 2a, that cash paid deals outperform share paid deals at least at the announcement date. 
This result can be explained with asymmetric information and the information advantage of management that signals their perspective on the value generating opportunities of deals with their choice of the method of payment. Deals with expected high returns are paid for with cash and deals where the bidder wants that the target shareholder share the potential risks are paid for with shares. Studies such as Martynova and Renneboog (2009), Fuller et al. (2002) and Moeller et al. (2005) present similar results.

Table 10. Cumulative abnormal returns of the payment determinants

\begin{tabular}{|c|c|c|c|c|c|}
\hline & {$[-10 ;+10]$} & {$[-3 ;+3]$} & {$[-1 ;+1]$} & [0] & Obs \\
\hline \multirow[t]{2}{*}{ Cash } & 0.0348 & 0.0336 & 0.0292 & 0.0192 & \multirow{2}{*}{560} \\
\hline & $(0.0210)$ & $(0.0249)$ & $(0.0169)$ & $(0.0048)$ & \\
\hline \multirow[t]{2}{*}{ Shares } & 0.0298 & 0.0228 & 0.0197 & 0.0104 & \multirow{2}{*}{157} \\
\hline & $(0.0219)$ & $(0.0078)$ & $(0.0125)$ & $(0.0027)$ & \\
\hline \multirow[t]{2}{*}{ Total } & 0.0336 & 0.0312 & 0.0271 & 0.0172 & \multirow{2}{*}{717} \\
\hline & $(0.0214)$ & $(0.0208)$ & $(0.0154)$ & $(0.0044)$ & \\
\hline
\end{tabular}

Table 11. Two sample Mann-Whitney test - payment methods

\begin{tabular}{|l|l|l|l|}
\hline & Z-score & P-value & \\
\hline AR $[0]$ & 1.713 & 0.0867 & $*$ \\
\hline CAR $[-1 ;+1]$ & 1.292 & 0.1965 & \\
\hline CAR $[-10 ;+10]$ & -0.074 & 0.9413 & \\
\hline \multicolumn{4}{|l|}{} \\
Table 11 shows the Mann-Whitney test by comparing the means of the payment methods. \\
The columns present the Z-score and P-value. The significance levels are: *,**** for \\
$10 \%, 5 \%$, and the 1\% level.
\end{tabular}


The graphical presentations in Figures $4 \mathrm{a}$ and $4 \mathrm{~b}$ support our expectations and findings so far. For cash payments, there are no valuation effects before the announcement, substantial valuation effects around the announcement of more than $3 \%$, and hardly any stock price reactions subsequently, supporting efficient market arguments. For share payments, we observe different results, which are consistent with the previous observation we gained from our analysis presented in Table 10. Over the pre-announcement period $(-30 ;-10)$, we observe negative cumulative valuation effects of up to minus $2 \%$. There are positive stock price reactions thereafter of about $4 \%(-9 ;+6)$ including a $1 \%$ increase at the announcement day. Thereafter, we identify some negative stock price reactions of about minus $1 \%(+7$; +30 ), resulting in cumulative abnormal returns of about $1 \%$ for the entire period ($30 ;+30)$. Overall, paying for a deal with cash instead of shares results in a three percentage points higher positive valuation effect for the bidder firm as cash payments may signal management's confidence in the quality and success of the merger or acquisition.

Figure 4a. Cumulative abnormal returns of payment methods

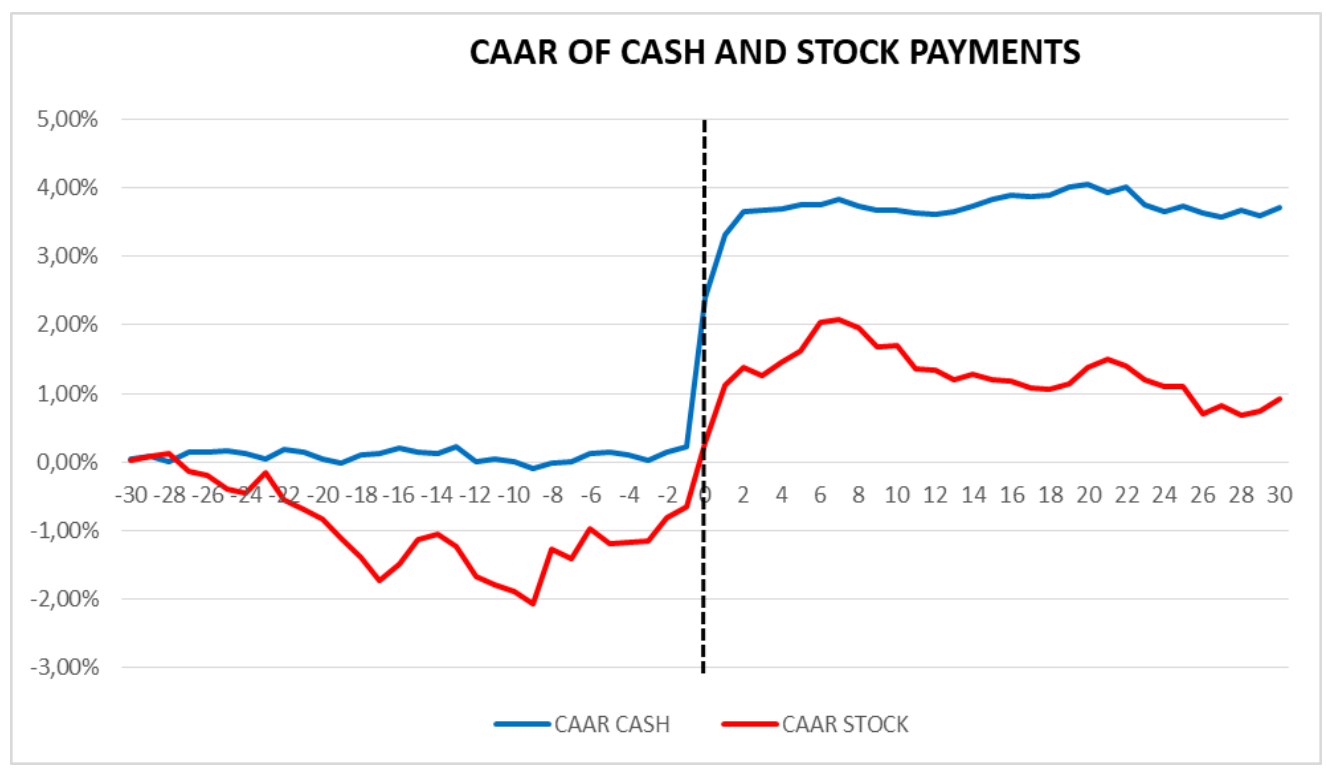


Figure 4b. Abnormal returns of payment methods

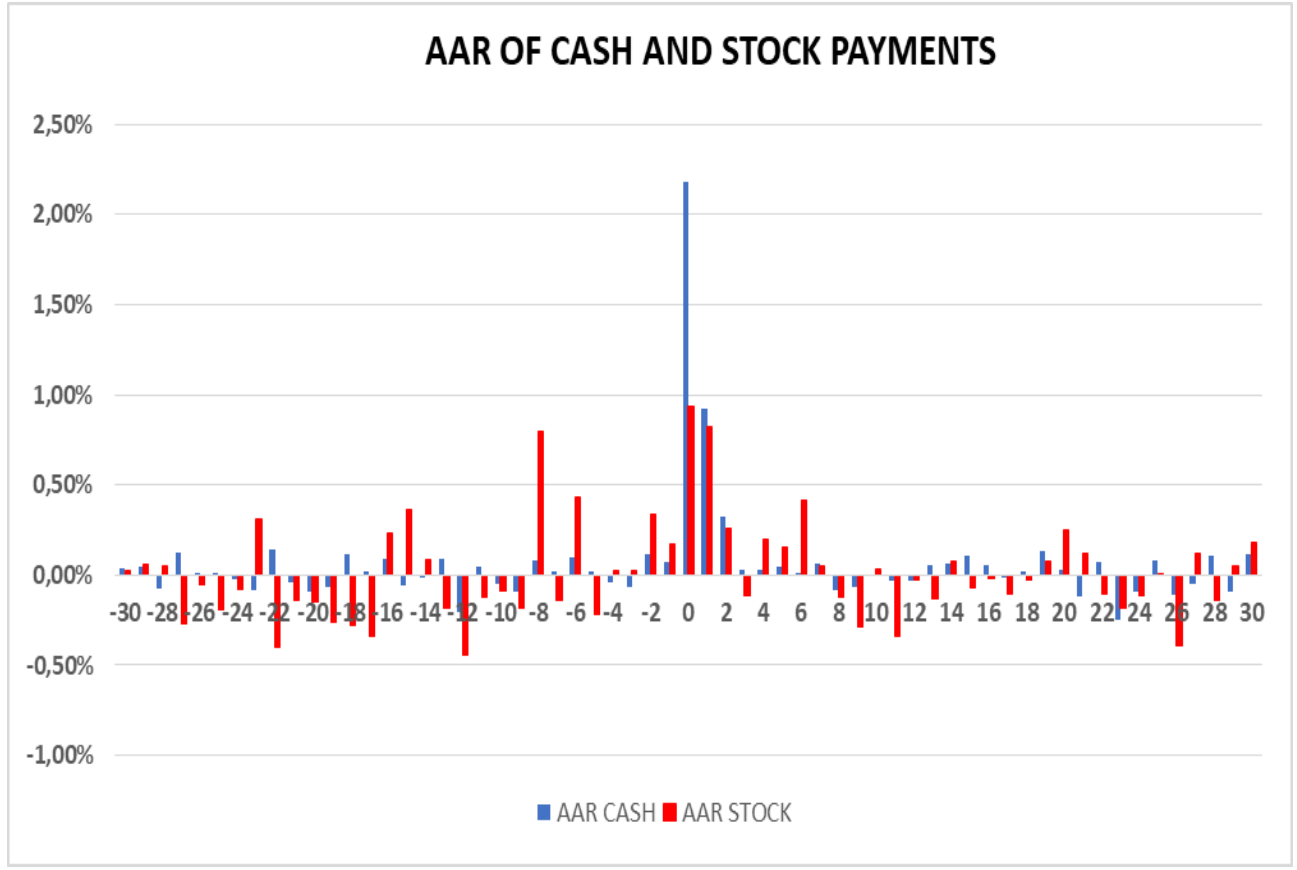

Cash - number of observations $=560$.

Stock - number of observations $=157$.

We now turn our attention on the bidder returns and the results from the regression analysis with respect to the method of payment. Table 12 contains the results from single (models 1,2, and 5,6) and multiple regressions (models 3,4, and 7,8 ) of the explanatory variable(s) on the abnormal returns for cash and stock paid acquisitions. The impact of multiple explanatory variables on the CAARs of the debt and equity transactions is analysed as well. Models 1-4 include the regression for the longer window $(-10 ;+10)$, and models $5-8$ for the event day $(-1 ;+1)$. The regression consists of several control variables: Transaction Value, Cash, Market-to-Bookratio, Firm Size, Profitability, and Asset Tangibility, followed by dummies that control for different industries, non-financials/utilities, public targets, and crossborder takeovers. The payment method is a binary variable, indicating whether companies paid their transactions with cash or equity. We illustrate the single 


\section{Wolfgang BESSLER, David KRUIZENGA, Wim WESTERMAN}

regression on the short-term window mathematically (models 5 and 6 first row in Table 12).

(12) CAAR $_{t}$ Cash $=0.0292-0.0095 *$ Equity

(13) CAARt Stock $=0.0197+0.0095 *$ Cash

The single regression conveys that cash payments generate significantly higher abnormal returns than stock paid acquisitions for both windows (3.38\% vs. $2.92 \%$ and $2.98 \%$ vs. $0.197 \%$ ). In addition, model 5 and 7 indicate that cash payments have a statistically significant effect on the abnormal returns for a window of three days around the announcement. The cumulative abnormal returns and therefore the valuation effects are economically relevant. This implies that investors have more confidence in the quality of cash paid takeovers, because cash payments are interpreted as a positive signal to the market (Fischer 2017; Majluf, Myers 1984).

Profitability expressed as EBITDA divided by total assets reveals opposite reactions on cash and stock paid acquisitions. The models predict that an increase in profitability reduces the abnormal returns for cash paid takeovers. As the effect is significant only at the $10 \%$ level (see Model 3) we give less importance to this finding. The binary variable that specifies the financial and utility companies suggest that acquiring companies outside the financial and utility industry leads to significant higher abnormal returns in the longer window $(-10 ;+10)$. Moreover, cash paid acquisitions of public targets face a substantial and significant decline of the market value. Consequently, the significant effects of public targets on the payment method are driven by the cash paid acquisitions. In addition, the total amount of cash is significantly negative for companies paying with stock (Model 4). It remains unclear how to interpret this effect, because the relative size is not observable. Yet, consistent with the pecking order theory (Majluf, Myers 1984), this implies that firms with sufficient cash levels would use cash for acquisitions. 
Table 12. Single and multiple regression of the effects on cash and stock paid takeovers (see footnote 1 next page)

\begin{tabular}{|c|c|c|c|c|c|c|c|c|}
\hline Model & 1 & 2 & 3 & 4 & 5 & 6 & 7 & 8 \\
\hline Payment Method & Cash & Stock & Cash & Stock & Cash & Stock & Cash & Stock \\
\hline Variables/Periods & $(-10 ;+10)$ & $(-10 ;+10)$ & $(-10 ;+10)$ & $(-10 ;+10)$ & $(-1 ;+1)$ & $(-1 ;+1)$ & $(-1 ;+1)$ & $(-1 ;+1)$ \\
\hline \multirow[t]{2}{*}{ Constant } & $0.0348 * * *$ & $0.0298 * * *$ & -0.00565 & 0.114 & $0.0292 * * *$ & $0.0197 * * *$ & $0.115^{* * *}$ & $0.169 *$ \\
\hline & $(0.00552)$ & $(0.00989)$ & $(0.0729)$ & $(0.119)$ & $(0.00305)$ & $(0.00596)$ & $(0.0388)$ & \begin{tabular}{|l}
$(0.0869)$ \\
\end{tabular} \\
\hline \multirow[t]{2}{*}{ Transaction V. } & & & -0.0000 & -0.0000 & & & -0.0000 & -0.0000 \\
\hline & & & $(0.0000)$ & $(0.0000)$ & & & \begin{tabular}{|l}
$(0.0000)$ \\
\end{tabular} & \begin{tabular}{|l}
$(0.0000)$ \\
\end{tabular} \\
\hline \multirow[t]{2}{*}{ Cash } & & & -0.0000 & $-0.0000 * * *$ & & & \begin{tabular}{|l|}
0.0000 \\
\end{tabular} & \begin{tabular}{|l|}
-0.0000 \\
\end{tabular} \\
\hline & & & $(0.0000)$ & $(0.0000)$ & & & \begin{tabular}{|l|}
$(0.0000)$ \\
\end{tabular} & \begin{tabular}{|l|}
$(0.0000)$ \\
\end{tabular} \\
\hline \multirow[t]{2}{*}{$\mathrm{MB}$} & & & -0.00256 & $-0.00966 * * *$ & & & \begin{tabular}{|l|}
-0.000572 \\
\end{tabular} & 0.000285 \\
\hline & & & $(0.00161)$ & $(0.00331)$ & & & $(0.00101)$ & $\begin{array}{l}(0.00159) \\
\end{array}$ \\
\hline \multirow[t]{2}{*}{ Firm size } & & & 0.00189 & -0.0131 & & & $-0.0103 * *$ & $-0.0183 *$ \\
\hline & & & \begin{tabular}{|l|}
$(0.00786)$ \\
\end{tabular} & $(0.0135)$ & & & $(0.00415)$ & $(0.00942)$ \\
\hline \multirow[t]{2}{*}{ Profitability } & & & $-0.00121 *$ & 0.00225 & & & \begin{tabular}{|l|}
$-7.01 e-05$ \\
\end{tabular} & \begin{tabular}{|l|}
0.00175 \\
\end{tabular} \\
\hline & & & $(0.000619)$ & $(0.00249)$ & & & $(0.000284)$ & \begin{tabular}{|l}
$(0.00157)$ \\
\end{tabular} \\
\hline \multirow[t]{2}{*}{ Asset tangibility } & & & $0.000828 * * *$ & -0.00174 & & & 0.000179 & \begin{tabular}{|l|}
-0.00147 \\
\end{tabular} \\
\hline & & & $(0.000232)$ & $(0.00141)$ & & & $(0.000122)$ & \begin{tabular}{|l}
$(0.000919)$ \\
\end{tabular} \\
\hline \multirow[t]{2}{*}{ Different industry } & & & $0.0195^{*}$ & 0.0158 & & & 0.00449 & -0.0184 \\
\hline & & & $(0.0113)$ & $(0.0204)$ & & & \begin{tabular}{|l|}
$(0.00646)$ \\
\end{tabular} & \begin{tabular}{|l|}
$(0.0134)$ \\
\end{tabular} \\
\hline \multirow[t]{2}{*}{ Non-fin./utility } & & & $0.0323^{* *}$ & $0.0433^{*}$ & & & 0.00811 & 0.00721 \\
\hline & & & $(0.0150)$ & $(0.0221)$ & & & $(0.00807)$ & \begin{tabular}{|l|}
$(0.0197)$ \\
\end{tabular} \\
\hline \multirow[t]{2}{*}{ Public target } & & & $-0.0702 * * *$ & 0.0172 & & & $-0.0467 * * *$ & \begin{tabular}{|l|}
0.0101 \\
\end{tabular} \\
\hline & & & $(0.0145)$ & $(0.0309)$ & & & \begin{tabular}{|l}
$(0.00873)$ \\
\end{tabular} & \begin{tabular}{|l}
$(0.0201)$ \\
\end{tabular} \\
\hline \multirow[t]{2}{*}{ Cross-border } & & & -0.0107 & 0.0213 & & & -0.00207 & \begin{tabular}{|l|}
0.0259 \\
\end{tabular} \\
\hline & & & $(0.0139)$ & $(0.0260)$ & & & $(0.00740)$ & \begin{tabular}{|l|}
$(0.0159)$ \\
\end{tabular} \\
\hline Robust & No & No & Yes & Yes & No & No & Yes & Yes \\
\hline Observations & 560 & 157 & 481 & 134 & 560 & 157 & 481 & 134 \\
\hline R-squared & 0.000 & 0.000 & 0.086 & 0.194 & 0.000 & 0.000 & 0.110 & 0.103 \\
\hline
\end{tabular}




\subsection{Interaction between financing sources and methods of payments}

So far, we have analyzed the effects of the alternative financing sources and the different methods of payment on the magnitude of the abnormal bidder returns separately. However, it can be expected that there exists some interaction effect between two variables caused by information asymmetry and signaling as well as due to agency problems. In Figures $5 \mathrm{a}$ and $5 \mathrm{~b}$ we present the cumulative abnormal returns for all combinations between these two categories. The following four combinations of financing and payment decisions are possible: debt and cash, equity and shares (Figure 5a) as well as debt and shares, and equity and cash (Figure 5b). Based on the literature and our previous results, we expect that the information asymmetry and the agency problems are minimized and the positive signaling effect is maximized when firms finance the deal with debt and pay with cash. In contrast, equity financing and paying with shares signals the low profitability and riskiness of the acquisition and a likely inferior outcome of the deal.

The CAARs in Figure 5a provide convincingly supporting evidence for our conjecture in that the debt/cash combination generates the highest positive abnormal returns at the announcement. There is no run-up or decline before, but persisting returns of about $4 \%$ afterwards. In contrast, the combination equity/shares offers the lowest valuation effects in that the returns are negative before and positive at the announcement, but decline thereafter again, indicating the market participants' perspective that a deal for which management selects this combination signals its uncertainty and low value creation potential. Interestingly, the negative valuation effect of equity financing before the M\&A may be due to the typical negative equity issuance effect.

Each pair in the combinations in figure $5 \mathrm{~b}$ includes one positive (debts or cash) and one negative signaling device (equity or shares). This results in insignificantly abnormal returns before the M\&A announcement, some positive valuation effects at the deal announcement, and persistent returns subsequent to the announcement of around $4 \%$, however, with some fluctuations. Surprisingly, the post-announcement

1 In Table 12, figures in parentheses are the (robust) standard errors. The values are winsorized at the lower $1 \%$ and upper $99 \%$. The significance levels are *, **, ***, which stands for $10 \%, 5 \%$, and the $1 \%$ level. 
return level is similar to that of debt/cash deals, which we interpret as the best signaling combination. However, it seems plausible that the market does not need both signals simultaneously as one signal may suffice and does convince investors. For example, issuing equity is not that devastating as long as the method of payment is cash, because the equity issuing could have been motivated by other reasoning such as reducing leverage or adjusting the capital structure. Similar arguments could be made for the debt/shares combination as it includes the positive debt financing instrument.

Figure 5a. Abnormal returns of payment methods and financing sources

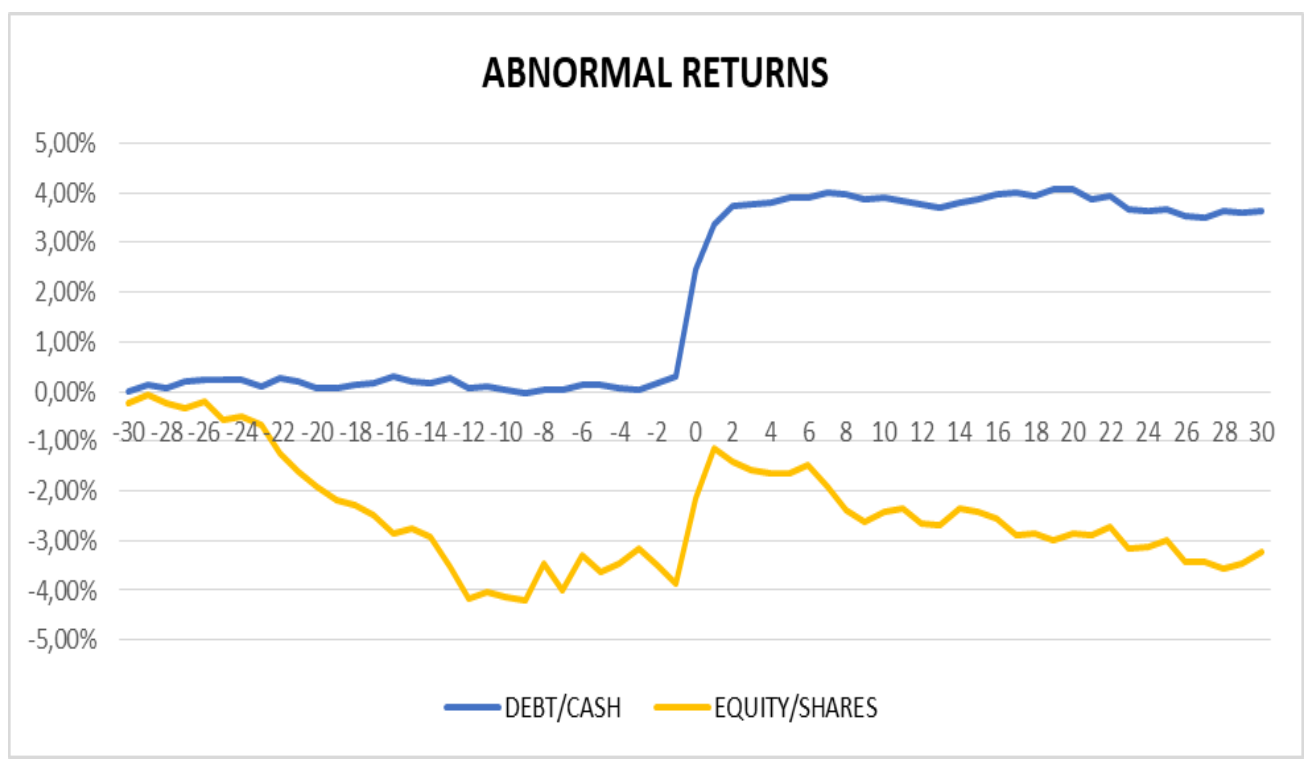

Debt $/$ Cash - number of observations $=464$.

Equity/Shares - number of observations $=71$. 
Figure 5b. Abnormal returns of payment methods and financing sources

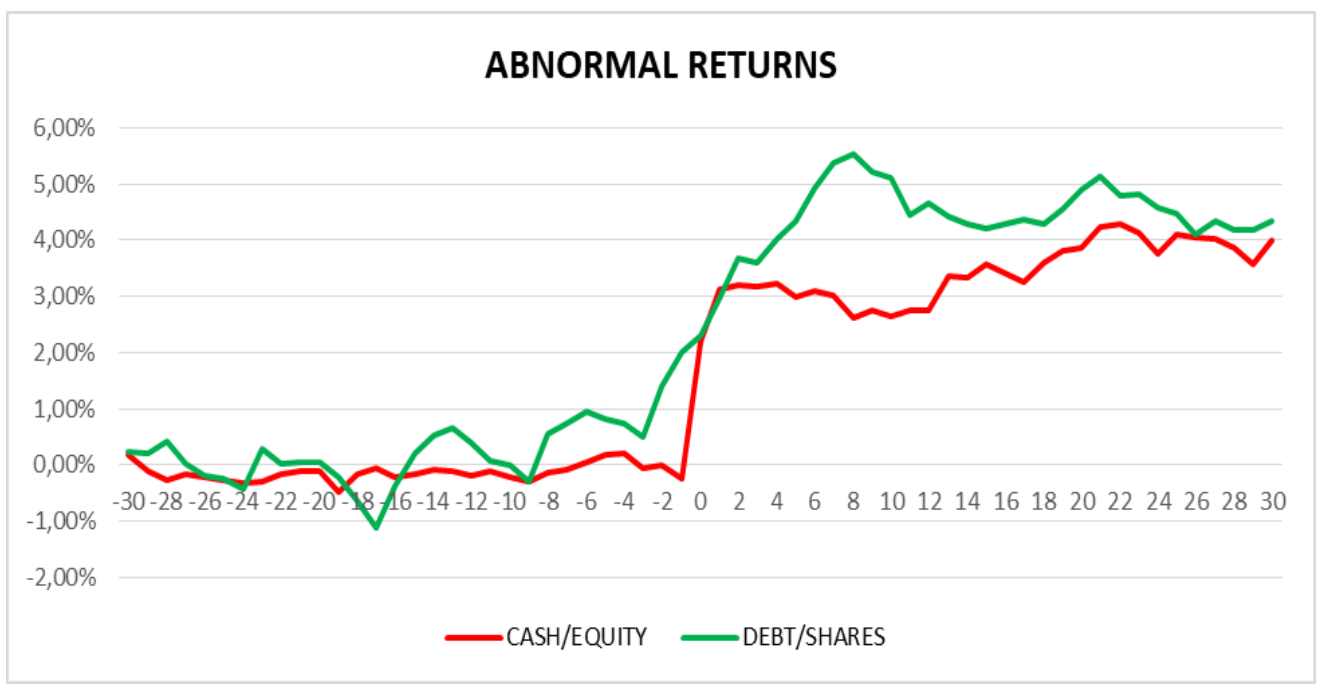

Equity/Cash - number of observations $=94$.

Debt/Shares - number of observations $=86$.

\subsection{Targets: cumulative abnormal returns and methods of payment}

So far, we were mostly interested in the merger related returns for the bidder and the effects that the financing and payment decision had on the magnitude of these returns. We now turn to the target and analyze how the different methods of payment affect the size of the valuation effects. This analysis can only be considered as indicative as the majority of the targets in our sample are privately owned and only less than 100 firms are publicly traded. In Table 13 we present our findings for the subsample of publicly traded targets and find that cash bids generate more positive wealth effects for target shareholders than share deals. Although the abnormal target returns are insignificant, the magnitude suggest that they are economically relevant. The announcement day (0) abnormal returns for targets are higher for cash deals (13.30\%) than for share deals $(6.93 \%)$, suggesting that the selection of the method of payment by the bidder's management has a signaling effect on the quality and future prospect of the combined firm. In the share deal the target shareholders usually become shareholders of the bidder and this does not 
seem to be a great value generating proposition. The relationships also hold for longer event windows, although the difference decreases for longer intervals. The research offers patterns in accordance with the results in Goergen and Renneboog (2004) and Martynova and Renneboog (2009). Both provide evidence that cash payments generate significantly higher returns for target shareholders, which are economically sensible findings.

Table 13. Cumulative abnormal returns of payment determinants

\begin{tabular}{|c|c|c|c|c|c|}
\hline & {$[-10 ;+10]$} & {$[-3 ;+3]$} & {$[-1 ;+1]$} & {$[0]$} & Obs \\
\hline \multirow[t]{2}{*}{ Cash } & 0.2081 & 0.1820 & 0.1664 & 0.1330 & \multirow{2}{*}{73} \\
\hline & $(0.1583)$ & $(0.1478)$ & $(0.1287)$ & $(0.0961)$ & \\
\hline \multirow[t]{2}{*}{ Shares } & 0.1684 & 0.1256 & 0.1065 & 0.0693 & \multirow{2}{*}{19} \\
\hline & $(0.1561)$ & $(0.1208)$ & $(0.0689)$ & $(0.0371)$ & \\
\hline \multirow[t]{2}{*}{ Total } & 0.1999 & 0.1703 & 0.1540 & $\begin{array}{l}0.1198 \\
\end{array}$ & \multirow{2}{*}{92} \\
\hline & $(0.1573)$ & $(0.1239)$ & $(0.1021)$ & $(0.0692)$ & \\
\hline
\end{tabular}

\section{Conclusions}

In this study, we analyze the stock price reactions and short-term performance effects of bidder and target firms engaging in European domestic and cross-border acquisitions. The focus is on the short-term valuation effects of 717 European merger transactions. We use event study methodology to determine the abnormal returns around the merger announcement. The empirical findings suggest that bidder firms benefit substantially from the merger announcement. The evidence for target firms is consistent with the previous M\&A literature as the bidder has to pay a premium for acquiring the target, which often represents the entire expected synergy gains (Bessler, Schneck 2015). For bidder firms we also find positive abnormal returns for the full sample at the announcement day, a run-up before and no substantial abnormal returns subsequently. The positive outcome for bidder firms is 


\section{Wolfgang BESSLER, David KRUIZENGA, Wim WESTERMAN}

primarily determined by the acquisition of private targets. For public targets our findings are in line with most of the previous literature that does not find any significantly positive bidder announcement returns. Only more recent studies report positive valuation effects for the bidder (Martynova, Renneboog 2009; Alexandris et al. 2010). However, as most of our target firms are privately owned the results are consistent with the previous literature.

Most importantly, the focus of our analysis is on explaining the magnitude of the abnormal bidder and target announcement returns by differentiating between alternative financing sources and alternative methods of payment in mergers and acquisitions (Bessler, Drobetz, Zimmermann 2011; Bharadwaj, Shivdasani 2003; Martynova, Renneboog 2009; Fischer 2017). For bidder shareholders we observe that debt financing generates significantly higher abnormal returns than equity financing, which is in line with previous studies by Martynova and Renneboog (2009) and Fischer (2017). Consequently, in financial markets characterized by information asymmetry, management is assumed to be better informed than shareholders and may reveal their information advantage to public equity markets through specific actions such as financing decisions. Moreover, agency theory does also suggest that debt financing is usually preferred over equity financing for deals offering the highest expected rates of return and the lowest uncertainty. The evidence related to the method of payment suggest that cash payments generate higher valuation effects relative to stock payments, at least in the days surrounding the merger announcement. This finding is consistent with studies by Fuller et al. (2002) and Moeller et al. (2005). Again the signaling argument but also the agency theory aspects apply here as well, as management typically prefers to share the potential losses of risky M\&As with the target shareholder by paying with shares, but, in contrast, being eager to keeping the benefits of the more valuable and less risky M\&As for themselves by paying with cash.

Overall, the above results appear consistent with the pecking order theory as debt issuance seems preferable to equity financing, resulting in positive valuation effects. Moreover, agency theory suggests that for the most promising deals bidders would always issue debt and pay with cash. This study indicates that both the financing source and the method of payment have significant effects on the size of 
the bidder and target returns. Consequently, both financing and payment decisions are relevant for analyzing the valuation effects of mergers and acquisitions.

\section{References}

Alexandris G., Petmezas D., Travlos N.G. (2010), Gains from mergers and acquisitions around the world. New evidence, "Journal of Financial Management”, vol. 39 no. 4, pp. 1671-1695.

Alexandridis G., Mavrovitis Ch.F., Travlos N.G. (2012), How have M\&As changed? Evidence from the sixth merger wave, "European Journal of Finance", vol. 18 no. 8, pp. 663-688.

Alexandridis G., Fuller K.P., Terhaar L., Travlos N.G. (2013), Deal size, acquisition premia and shareholder gains, "Journal of Corporate Finance”, vol. 20 no. 1, pp. 1-13.

Alexandridis G., Antypas N., Travlos N.G. (2017), Value creation from M\&As. New evidence, "Journal of Corporate Finance", vol. 45C, pp. 632-650.

Andrade G., Mitchell M., Stafford E. (2001), New evidence and perspectives on mergers, "Journal of Economic Perspectives", vol. 15 no. 2, pp. 103-120.

Asquith P. (1983), Merger bids, uncertainty, and stockholder returns, "Journal of Financial Economics", vol. 11 no. 1-4, pp. 51-83.

Ball R. (1978), Anomalies in relationships between securities' yields and yield-surrogates, "Journal of Financial Economics", vol. 6 no. 2-3, pp. 103-126.

Bessler W., Drobetz W., Pensa P. (2008), Do managers adjust the capital structure to market value changes. Evidence from Europe, "Zeitschrift für Betriebswirtschaft", Special Issue: 50 Years after Modigliani \& Miller: recent developments in corporate finance, no. 6, pp. 113-145.

Bessler W., Drobetz W., Kazemieh R. (2011), Factors affecting capital structure decisions, in: Capital structure and corporate financing decisions, Baker K., Martin J. (eds.), Kolb Series in Finance, John Wiley \& Sons, New York, pp. 17-40.

Bessler W., Drobetz W., Grüninger M.C. (2011), Information asymmetry and financing decisions, International Review of Finance 11, 123-154.

Bessler, W., Drobetz, W., Zimmermann, J. (2011), Capital structure and corporate financing decisions: Valuation, strategy and risk analysis. in: K. Baker and J. Martin (editors): Capital Structure and Corporate Financing Decisions, John Wiley \& Sons, New York, 2011, 419-444.

Bessler W., Schneck C. (2015), Excess Premium Offers and Bidder Success in European Takeovers, Eurasian Economic Review, 23-62.

Bessler W., Schneck C., Zimmermann J. (2015), Bidder contests in international mergers and acquisitions: The impact of toeholds, preemptive bidding, and termination fees, "International Review of Financial Analysis", vol. 42, pp. 4-23. 


\section{Wolfgang BESSLER, David KRUIZENGA, Wim WESTERMAN}

Bessler W., Schneck C., Zimmermann J. (2017), Growth strategies of initial public offerings in Europe, Working Paper, University of Giessen.

Bharadwaj A., Shivdasani A. (2003), Valuation effects of bank financing in acquisitions, "Journal of Financial Economics", vol. 67 no. 1, pp. 113-148.

Brown S., Warner J. (1980), Measuring security price performance, "Journal of Financial Economics", vol. 8 no. 3 , pp. $205-258$.

Brown S., Warner J. (1985), Using daily stock returns. The case of event studies, "Journal of Financial Economics", vol. 14, pp. 3-31.

Cho H., Ahn H.S. (2017), Stock payment and the effects of institutional and cultural differences. A study of shareholder value creation in cross-border M\&As, "International Business Review", vol. 26 no. 3, pp. 461-475.

Cornaggia J., Li J.Y. (2019), The value of access to finance. Evidence from M\&As, "Journal of Financial Economics", vol. 131 no. 1, pp. 232-250.

Dutta S., Saadi S., Zhu P.C. (2013), Does payment method matter in cross-border acquisitions?, "International Review of Economics and Finance", vol. 25, pp. 91-107.

Faccio M., Masulis R. (2005), The choice of payment method in European mergers and acquisitions, "Journal of Finance", vol. 60, pp. 1345-1388.

Fama E. (1965), The behavior of stock market prices, "Journal of Business”, vol. 38 no. 1, 34-105.

Fama E. (1970), Efficient capital markets. A review of theory and empirical work, "Journal of Finance", vol. 25 no. 2, pp. 383-417.

Fama E. (1991), Efficient capital markets II, “Journal of Finance”, vol. 46 no. 5, pp. 1575-1617.

Fich E.M., Nguyen T., Officer M. (2018), Large wealth creation in mergers and acquisitions, "Financial Management", vol. 47 no. 4, pp. 953-991.

Fischer M. (2017), The source of financing mergers and acquisitions, "Quarterly Review of Economics and Finance", vol. 65C, pp. 227-239.

Fuller K., Netter J., Stegemoller M. (2002), What do returns to acquiring firms tell us? Evidence from firms that make many acquisitions, "Journal of Finance", vol. 57 no. 4, pp. 1763-1793.

Golubov A., Petmezas D., Travlos N.G. (2016), Do stock-financed acquisitions destroy value? New methods and evidence, "Review of Finance", vol. 20, pp. 161-200.

Goergen M., Renneboog L. (2004), Shareholder wealth effects of European domestic and cross-border takeover bids, "European Financial Management", vol. 10 no. 1, pp. 9-45.

Grossman S., Stiglitz J. (1980), On the impossibility of informationally efficient markets, "American Economic Review", vol. 70 no. 3, 393-408. 


\section{STOCK MARKET REACTIONS TO FINANCING AND PAYMENT DECISIONS ...}

Harford J., Klasa S., Walcott N. (2006), Do firms have leverage targets? Evidence from acquisitions, "Journal of Financial Economics", vol. 93 no. 1, pp. 1-14.

Huang P., Officer M., Powell R. (2016), Method of payment and risk mitigation in cross-border mergers and acquisitions, "Journal of Corporate Finance", vol. 40, pp. 216-234.

Huber P. (1967), The behavior of maximum likelihood estimated under nonstandard conditions, Proceedings of the Fifth Berkeley Symposium on Mathematical Statistics and Probability 1, pp. 221233.

Ismael A., Krause A. (2010), Determinants of the method of payment in mergers and acquisitions, "Quarterly Review of Economics and Finance", vol. 50, pp. 471-484.

Jensen M., Meckling W. (1976), Theory of the firm. Managerial behavior, agency costs and ownership structure, "Journal of Financial Economics", vol. 3 no. 4, pp. 305-360.

Jensen M., Ruback R. (1983), The market for corporate control. The scientific evidence, "Journal of Financial Economics", vol. 11, pp. 5-50.

Kahle K., Walkling R. (1996), The impact of industry classifications on financial research, "Journal of Financial and Quantitative Analysis", vol. 31 no. 3, pp. 309-355.

La Porta R., Lopez-de-Silanes F., Scheiffer A., Vishny R. (1998), Law and finance, "Journal of Political Economics", vol. 106, pp. 1113-1147.

Lapron L., Shen J.C. (2007), Acquisitions of private vs. public firms. Private information, target selection, and acquirer returns, "Strategic Management Journal", vol. 28 no. 9, pp. 891-911.

Lie E., Liu Y. (2018), Corporate cash holdings and acquisitions, "Financial Management", vol. 47 no. 1 , pp. 159-173.

Luypaert M., Van Caneghem T. (2017), Exploring the double-sided effect of information asymmetry and uncertainty in mergers and acquisition, "Financial Management", vol. 46 no. 4, pp. 873-917.

MacKinlay C. (1997), Event studies in economics and finance, "Journal of Economic Literature", vol. 35, pp. 13-39.

Maiti J., Pradhan V. (2009), Bias reduction and a solution for separation of logistic regression with missing covariates, "Biometrics", vol. 65 no. 4, pp. 1262-1269.

Majluf N., Myers S. (1984), Corporate financing and investment decisions when firms have information that investors do not have, "Journal of Financial Economics", vol. 13, pp. 187-221.

Markowitz H. (1952), Portfolio selection, “Journal of Finance”, vol. 7 no. 1, pp. 77-91.

Malmendier U., Moretti E., Peters F.S. (2018), Winning by losing. Evidence on the long-run effects of mergers, "Review of Financial Studies", vol. 31 no. 8, pp. 3212-3264.

Martynova M., Renneboog L. (2009), What determines the financing decision in corporate takeovers. Cost of capital, agency problems, or the means payment?, "Journal of Corporate Finance", vol. 15 no. 3, pp. 1-42. 


\section{Wolfgang BESSLER, David KRUIZENGA, Wim WESTERMAN}

Mateev M. (2017), Is the M\&A announcement effect different across Europe? More evidences from continental Europe and the UK, "Research in International Business and Finance", vol. 40, pp. 190216.

Mitchell M., Mulherin J. (1996), The impact of industry shocks on takeover and restructuring activity, "Journal of Financial Economics", vol. 41, 193-229.

Miller M.H., Modigliani F. (1961), Dividend policy, growth and the valuation of shares, "The Journal of Business", vol. 34 no. 4, pp. 411-433.

Modigliani F., Miller M.H. (1958), The cost of capital, corporation finance and the theory of investment, "American Economic Review", vol. 48 no. 3, pp. 261-297.

Moeller S., Schlingemann F., Stulz R. (2005), Wealth destruction on a massive scale? A study of acquiring-firm returns in the recent merger wave, "Journal of Finance", vol. 60 no. 2, pp. 757-782.

Myers S. (1977), Determinants of corporate borrowing, "Journal of Financial Economics", vol. 5 no. 2 , pp. 147-175.

Peng H., Officer M.C., Powell R. (2016), Method of payment and risk mitigation in cross-border mergers and acquisitions, "Journal of Corporate Finance", vol. 40, pp. 216-234.

Potter D. (2005), A permutation test for inference in logistic regression with small- and moderate-sized data sets, "Statistics in Medicine", vol. 24 no. 5, pp. 693-708.

Rasch D., Teuscher F., Guiard V. (2007), How robust are tests for two independent samples?, "Journal of Statistical Planning and Inference”, vol. 137 no. 8, pp. 2706-2720.

Roll R. (1986), The hubris hypothesis of corporate takeovers, "Journal of Business", vol. 59 no. 2, pp. 197-216.

Samer A., Barbopoulos L.G. (2018), The valuation effects of investor attention in stock-financed acquisitions, "Journal of Empirical Finance", vol. 45, pp. 108-125.

Sankar B., Bijay P. (2018), Payment methods in mergers and acquisitions. A theoretical framework, "International Journal of Accounting and Financial Reporting", vol. 8 no. 1, pp. 171-187.

Scholes M., Williams J. (1977), Estimating betas from nonsynchronous data, "Journal of Financial Economics", vol. 5 no. 3, pp. 309-327.

Sharpe F. (1964), Capital asset prices. A theory of market equilibrium under conditions of risk, "Journal of Finance", vol. 19 no. 3, pp. 425-442.

Slovin M.B., Sushka M.E., Polonchek J.A. (1993), The value of bank durability. Borrowers as bank stakeholders, "Journal of Finance", vol. 48 no. 1, pp. 247-266.

Spence M. (1973), Job market signaling, "Quarterly Journal of Economics”, vol. 87 no. 3, pp. 355-374.

Vermaelen T., Xu M. (2014), Acquisition finance and market timing, "Journal of Corporate Finance", vol. 25, pp. 73-91. 


\section{STOCK MARKET REACTIONS TO FINANCING AND PAYMENT DECISIONS ...}

Welch B. (1947), The generalization of student's problem when several different population variances are involved, "Biometrika", vol. 34, no. 1-2, pp. 28-35.

White H. (1980), A heteroskedasticity-consistent covariance matrix estimator and direct test for heteroskedasticity, "Econometrica", vol. 48 no. 4, pp. 817-838.

Xu E.Q. (2017), Cross-border merger waves, "Journal of Corporate Finance", vol. 46 no. C, pp. 207231. 